\title{
Organometallic indolo[3,2-c] quinolines versus indolo[3,2-d]benzazepines: synthesis, structural and spectroscopic characterization, and biological efficacy
}

\author{
Lukas K. Filak • Gerhard Mühlgassner • Michael A. Jakupec • \\ Petra Heffeter · Walter Berger • Vladimir B. Arion • \\ Bernhard K. Keppler
}

Received: 2 December 2009/Accepted: 7 March 2010/Published online: 6 April 2010

(c) The Author(s) 2010. This article is published with open access at Springerlink.com

\begin{abstract}
The synthesis of ruthenium(II) and osmium(II) arene complexes with the closely related indolo[3,2-c]quinolines $N$-(11H-indolo[3,2-c]quinolin-6-yl)-ethane-1,2diamine $\left(\mathbf{L}^{\mathbf{1}}\right)$ and $N^{\prime}$-(11H-indolo[3,2-c]quinolin-6-yl)$N, N$-dimethylethane-1,2-diamine $\left(\mathbf{L}^{\mathbf{2}}\right)$ and indolo[3,2-d]benzazepines $N$-(7,12-dihydroindolo-[3,2- $d][1]$ benzazepin6-yl)-ethane-1,2-diamine $\left(\mathbf{L}^{\mathbf{3}}\right)$ and $N^{\prime}$-(7,12-dihydroindolo[3,2-d][1]benzazepin-6-yl)- $N, N$-dimethylethane-1,2-diamine $\left(\mathbf{L}^{\mathbf{4}}\right)$ of the general formulas $\left[\left(\eta^{6}-p\right.\right.$-cymene $\left.) \mathrm{M}^{\mathrm{II}}\left(\mathbf{L}^{\mathbf{1}}\right) \mathrm{Cl}\right] \mathrm{Cl}$,
\end{abstract}

Electronic supplementary material The online version of this article (doi:10.1007/s00775-010-0653-y) contains supplementary material, which is available to authorized users.

L. K. Filak · G. Mühlgassner - M. A. Jakupec ·

V. B. Arion $(\bowtie) \cdot$ B. K. Keppler

Institute of Inorganic Chemistry,

University of Vienna,

Währinger Straße 42,

1090 Vienna, Austria

e-mail: vladimir.arion@univie.ac.at

P. Heffeter · W. Berger

Department of Medicine I,

Institute of Cancer Research,

Medical University of Vienna,

Borschkegasse 8a,

1090 Vienna, Austria

M. A. Jakupec · B. K. Keppler

Research Platform "Translational Cancer Therapy Research",

University of Vienna,

Währinger Straße 42,

1090 Vienna, Austria

P. Heffeter - W. Berger

Research Platform "Translational Cancer Therapy Research",

Medical University of Vienna,

Borschkegasse 8a,

1090 Vienna, Austria where $\mathrm{M}$ is $\mathrm{Ru}$ (4) and Os (6), $\left[\left(\eta^{6}-p\right.\right.$-cymene $) \mathrm{M}^{\mathrm{II}}\left(\mathbf{L}^{\mathbf{2}}\right)$ $\mathrm{Cl}] \mathrm{Cl}$, where $\mathrm{M}$ is $\mathrm{Ru}(\mathbf{5})$ and Os $(7)$, [( $\eta^{6}-p$-cymene)$\left.\mathrm{M}^{\mathrm{II}}\left(\mathbf{L}^{3}\right) \mathrm{Cl}\right] \mathrm{Cl}$, where $\mathrm{M}$ is $\mathrm{Ru}(\mathbf{8})$ and $\mathrm{Os}(\mathbf{1 0})$, and $\left[\left(\eta^{6}-p\right.\right.$ cymene) $\left.\mathrm{M}^{\mathrm{II}}\left(\mathbf{L}^{\mathbf{4}}\right) \mathrm{Cl}\right] \mathrm{Cl}$, where $\mathrm{M}$ is $\mathrm{Ru}(\mathbf{9})$ and $\mathrm{Os}(\mathbf{1 1})$, is reported. The compounds have been comprehensively characterized by elemental analysis, electrospray ionization mass spectrometry, spectroscopy (IR, UV-vis, and NMR), and X-ray crystallography $\left(\mathbf{L}^{\mathbf{1}} \cdot \mathrm{HCl}, \mathbf{4} \cdot \mathrm{H}_{2} \mathrm{O}, \mathbf{5}\right.$, and 9.2. $5 \mathrm{H}_{2} \mathrm{O}$ ). Structure-activity relationships with regard to cytotoxicity and cell cycle effects in human cancer cells as well as cyclin-dependent kinase (cdk) inhibition and DNA intercalation in cell-free settings have been established. The metal-free indolo[3,2-c]quinolines inhibit cancer cell growth in vitro, with $\mathrm{IC}_{50}$ values in the high nanomolar range, whereas those of the related indolo $[3,2-d]$ benzazepines are in the low micromolar range. In cell-free experiments, these classes of compounds inhibit the activity of cdk2/cyclin E, but the much higher cytotoxicity and stronger cell cycle effects of indoloquinolines $\mathbf{L}^{\mathbf{1}}$ and $\mathbf{7}$ are not paralleled by a substantially higher kinase inhibition compared with indolobenzazepines $\mathbf{L}^{\mathbf{4}}$ and 11, arguing for additional targets and molecular effects, such as intercalation into DNA.

Keywords Indolo[3,2- $d$ ] benzazepines . Indolo[3,2-c]quinolines $\cdot$ Osmium $\cdot$ Ruthenium
Abbreviations
cdk Cyclin-dependent kinase
DMSO Dimethyl sulfoxide
DTA Differential thermal analysis
ESI Electrospray ionization
$\mathrm{GI}_{50} \quad$ Fifty percent growth inhibition concentration
$\mathrm{IC}_{50} \quad$ Fifty percent inhibitory concentration 
MTT 3-(4,5-Dimethyl-2-thiazolyl)-2,5-diphenyl-2 $H$ tetrazolium bromide

PBS Phosphate-buffered saline

TGA Thermogravimetric analysis

THF Tetrahydrofuran

\section{Introduction}

The quinolin-2(1H)-one moiety (Structure 1$)$ is involved in a large number of biologically active compounds [1-8]. Cytotoxic activity of $\alpha$-methylidene- $\gamma$-butyrolactones bearing quinoline, coumarin, flavone, xanthone, and quinolin-2(1H)-one heterocycles has been studied, showing that the latter derivatives were the most potent antiproliferative agents [8]. Moreover, the indole backbone is a basic structural component of clinically used anticancer drugs, e.g., vinblastine [9] and vincristine [10].

Indolo-[3,2-c]quinolines $\mathbf{1 a}$ and $\mathbf{1 b}$, combining both structural units, namely quinolin-2(1H)-one and indole, are now available [11-13], and further derivatization enables chemical diversification of this class of fused heteroaromatics [14-17]. The compounds shown in Structure 2 were tested for cytotoxicity at the US National Cancer Institute in a panel of about 60 human cancer cell lines. The results of this screening showed that $\mathbf{1 a}$ and $\mathbf{1 b}$ exhibit respectable inhibitory activity, with mean $50 \%$ cell growth inhibition concentrations $\left(\mathrm{GI}_{50}\right)$ of 19.0 and $18.2 \mu \mathrm{M}$, respectively. Substitution at the lactam unit led to enhanced cytotoxicity $(\mathbf{2 a}, 4.26 \mu \mathrm{M}$ vs. $\mathbf{1 a}, 19.0 \mu \mathrm{M})$, which was further increased by converting the keto function in $\mathbf{2 a}$ and $\mathbf{2 b}$ into an oxime group, yielding $\mathbf{3} \mathbf{a}$ and $\mathbf{3 b}\left(\mathrm{GI}_{50}\right.$ values of 1.70 and $1.35 \mu \mathrm{M}$, respectively) [16].

All this indicates that this family of compounds is worth investigating further as potential antitumor drugs. Moreover, although the library of compounds created is remarkable, it lacks metal-based derivatives, and the effect of metal coordination of indolo[3,2-c]quinolines on the antiproliferative activity and biological mechanisms involved remained unexplored. This is even more intriguing when considering that indolo-[3,2- $d]$ benzazepines, also named paullones (Structure 3), which possess a molecular structure closely related to indolo[3,2-c]quinolines and were identified as cyclin-dependent kinase (cdk) inhibitors [18], can be readily coordinated to metals by creating

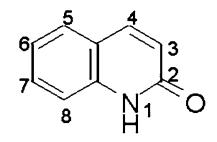

quinoline-2(1H)-one

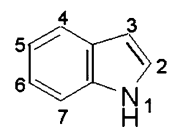

indole

Structure 1

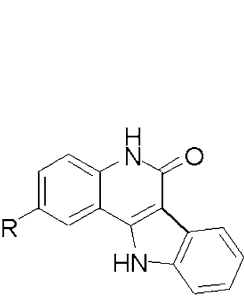

$1 \mathrm{a} R=\mathrm{H}$
$1 \mathrm{~b} R=\mathrm{C}$<smiles>[R]c1ccc2nc(Nc3cccc(C(C)=O)c3)c3c4ccccc4[nH]c3c2c1</smiles>

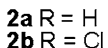<smiles>[R]c1ccc2nc(Nc3cccc(/C(C)=N/O)c3)c3c4ccccc4[nH]c3c2c1</smiles>

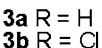

Structure 2

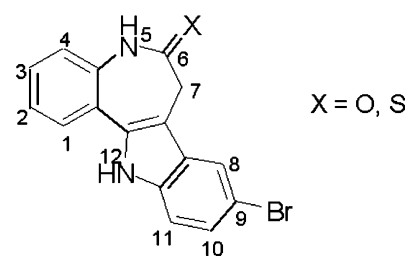

Structure 3 Kenpaullone and its thiolactam derivative

metal-binding sites at the periphery of the molecule skeleton able to accommodate metal ions, yielding complexes with high cytotoxicities and the ability to cause cell cycle perturbations [19-23]. Recently, a method to convert indolo[3,2- $d]$ benzazepines into the corresponding 6-(carboxylic acid)indolo[3,2-c]quinolines was published [24].

In pursuing the goal of developing effective metal-based antitumor drug candidates and establishing novel structure-cytotoxicity relationships, we deliberately chose two related systems for metal coordination, the indolo-[3,2-c] quinolines $\mathbf{L}^{\mathbf{1}}$ and $\mathbf{L}^{\mathbf{2}}$ and the indolo-[3,2- $d$ ] benzazepines $\mathbf{L}^{3}$ and $\mathbf{L}^{\mathbf{4}}$ (Structure 4). Compound $\mathbf{L}^{\mathbf{2}}$ was reported to exhibit high antiproliferative activity in human HL-60 leukemia cells $\left(\mathrm{GI}_{50}\right.$ of $\left.1.98 \mu \mathrm{M}\right)$, alter the cell cycle distribution via G2/M-phase (in human K562 leukemia cells) or S-phase arrest (in HL-60 cells), respectively, and induce apoptosis through the JNK signaling pathway (in K562 cells) [25-27]. We show herein that both indoloquinolines and indolobenzazepines can be easily attached to ruthenium arene and osmium arene scaffolds, allowing for the isolation, spectroscopic characterization, and testing for cytotoxicity of complexes 4-11 (Structure 4) in human cancer cell lines. The rationale for selection of these two organic systems for coordination to ruthenium and osmium was that it might enable (1) elucidation of the effect of metal coordination on the solubility of the organic compounds $\mathbf{L}^{\mathbf{1}}-\mathbf{L}^{\mathbf{4}}$ in aqueous solution and on in vitro antiproliferative activity in human cancer cell lines, and (2) study of the effect of substitution of the folded sevenmembered azepine ring in indolo[3,2- $d]$ benzazepines $\mathbf{L}^{3}$ and $\mathbf{L}^{\mathbf{4}}$ by a planar six-membered ring in $\mathbf{L}^{\mathbf{1}}$ and $\mathbf{L}^{\mathbf{2}}$ on solubility, thermal stability, hydrolytic behavior, spectroscopic properties, and antiproliferative activity of the corresponding metal-based derivatives shown in Structure 4. 

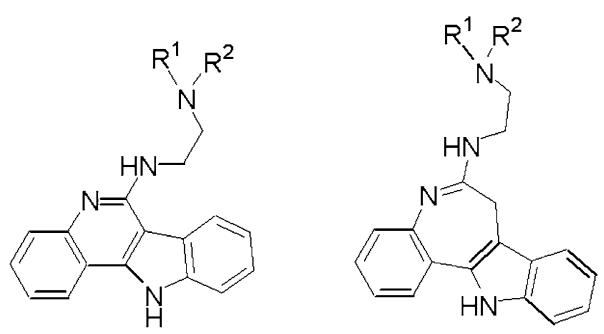

$L^{1}: R^{1}=R^{2}=H$ $\mathrm{L}^{2}: \mathrm{R}^{1}=\mathrm{R}^{2}=\mathrm{CH}_{3}$

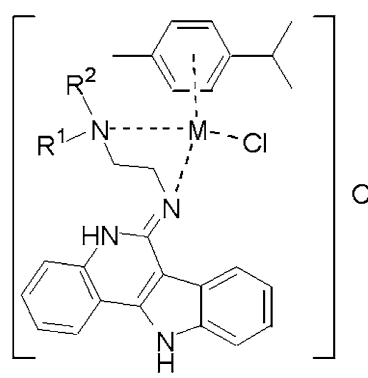

$$
\mathrm{L}^{3}: \mathrm{R}^{1}=\mathrm{R}^{2}=\mathrm{H}
$$$$
\mathrm{L}^{4}: \mathrm{R}^{1}=\mathrm{R}^{2}=\mathrm{CH}_{3}
$$

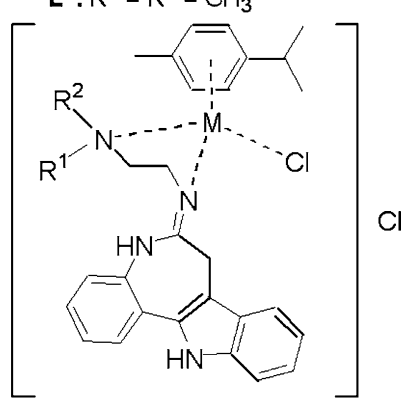

4: $M=R^{\prime l}, R^{1}=R^{2}=H$

$\underline{\mathbf{5}}: \mathrm{M}=\mathrm{Ru}^{\mathrm{II}}, \mathrm{R}^{1}=\mathrm{R}^{2}=\mathrm{CH}_{3}$

6: $M=O s^{\prime \prime}, R^{1}=R^{2}=H$

7: $M=O s^{\prime \prime}, R^{1}=R^{2}=\mathrm{CH}_{3}$

Structure 4 Underlining indicates compounds that were characterized by X-ray crystallography

We anticipated that this substitution would enhance markedly the ability of $\mathbf{L}^{\mathbf{1}}, \mathbf{L}^{\mathbf{2}}$, and their metal-based derivatives to intercalate into DNA, and result in different cytotoxicity when compared with that of $\mathbf{L}^{\mathbf{3}}, \mathbf{L}^{\mathbf{4}}$, and their metal-containing species. Via the ethane-1,2-diamine moiety the organic ligands were attached to ruthenium arene and osmium arene scaffolds, since this provides different ligand exchange rate kinetics at the metal, another parameter relevant for the creation of efficient metal-based antitumor drugs. Ruthenium and osmium arene complexes with ethane-1,2-diamine-based [28-30] or heteroaromatic [31-33] ligands are well documented in the literature, and extensive studies dealing with their biological, physical, and chemical properties have been published. Interestingly, the suggested modes of action vary strongly depending on the ligands and include, e.g., intercalation into DNA [31], kinase inhibition [33], cell cycle arrest [21], as well as topoisomerase inhibition [34]. We anticipated that complexation would sustain or enhance the biological activity of the ligands and alter the pharmacological properties.

\section{Materials and methods}

Materials

Ethanol and tetrahydrofuran (THF) were dried using standard procedures. 7,12-Dihydroindolo[3,2- $d][1]$ benzazepin-
6(5H)-thione was prepared according to a literature protocol [35]. $\quad N^{\prime}-(11 H$-Indolo[3,2-c]quinolin-6-yl)- $N, N$-dimethylethane-1,2-diamine was synthesized by modification of a reported procedure [25], as described later. $N, N$-Dimethylethane-1,2-diamine and ethane-1,2-diamine were purchased from Fluka/Aldrich and used without further purification. $\quad\left[\mathrm{Ru}^{\mathrm{II}} \mathrm{Cl}(\mu \text {-Cl })\left(\eta^{6}-p \text {-cymene }\right)\right]_{2} \quad[36]$ and $\left[\mathrm{Os}{ }^{\mathrm{II}} \mathrm{Cl}(\mu-\mathrm{Cl})\left(\eta^{6}-p \text {-cymene }\right)\right]_{2}$ [37] were synthesized as described in the literature. Flavopiridol (Alvocidib) was kindly provided by Sanofi-Aventis.

Preparation of the ligands and complexes

\section{$N$-(11H-Indolo[3,2-c]quinolin-6-yl)-ethane-1,2-diamine $\left(L^{1}\right)$}

A suspension of 6-chloro-11H-indolo[3,2-c]quinoline $(200 \mathrm{mg}, 0.79 \mathrm{mmol})$ and ethane-1,2-diamine $(530 \mu \mathrm{L}$, $8.00 \mathrm{mmol})$ in 1-butanol $(1.7 \mathrm{~mL})$ was heated at $132{ }^{\circ} \mathrm{C}$ for $26 \mathrm{~h}$ under an argon atmosphere. The reaction mixture was allowed to cool to room temperature, and the solvent was removed under reduced pressure. The residue was extracted with $0.1 \mathrm{M}$ aqueous $\mathrm{HCl}(6 \times 3-4 \mathrm{~mL})$. After filtration the $\mathrm{pH}$ was set to $9-10$ by addition of $\mathrm{Na}_{2} \mathrm{CO}_{3}$. The product formed was extracted with ethyl acetate $(5 \times 30 \mathrm{~mL})$, the combined organic phases were dried over $\mathrm{Na}_{2} \mathrm{SO}_{4}$, filtered, and the solvent was removed under reduced pressure. The white product was dried in vacuo. Yield: $186 \mathrm{mg}, 85 \%$. Anal. calcd. for $\mathrm{C}_{17} \mathrm{H}_{16} \mathrm{~N}_{4}\left(M_{\mathrm{r}}\right.$ 276.33): C, 73.89; H, 5.84; N, 20.27\%. Found: C, 73.63; H, 5.57; N, 20.34\%. Solubility in dimethyl sulfoxide (DMSO): $360 \mathrm{mM}$ or greater. Solubility in $1 \% \mathrm{DMSO} /$ phosphate-buffered saline (PBS): $275 \mu \mathrm{M}$ or greater. Single crystals of $\mathbf{L}^{\mathbf{1}} \cdot \mathrm{HCl}$ suitable for $\mathrm{X}$-ray diffraction were obtained by slow evaporation of an ethanolic solution of the raw product.

\section{$N^{\prime}$-(11H-Indolo[3,2-c]quinolin-6-yl)-N,N-dimethylethane- 1,2-diamine $\left(\boldsymbol{L}^{2}\right)$}

A suspension of 6-chloro-11H-indolo[3,2-c]quinoline (423 mg, $1.67 \mathrm{mmol}$ ) and $N, N$-dimethylethane-1,2-diamine $(440 \mu \mathrm{L}, 4.03 \mathrm{mmol})$ in 1-butanol $(3.5 \mathrm{~mL})$ was heated at $132{ }^{\circ} \mathrm{C}$ for $28 \mathrm{~h}$ under an argon atmosphere. The reaction mixture was allowed to cool to room temperature, and the solvent was removed under reduced pressure. The residue was dissolved in $0.1 \mathrm{M}$ aqueous $\mathrm{HCl}(70 \mathrm{~mL})$, and the $\mathrm{pH}$ of the solution was set to 5 by further addition of $0.1 \mathrm{M} \mathrm{HCl}$. After filtration the $\mathrm{pH}$ was set to $9-10$ by addition of $\mathrm{Na}_{2} \mathrm{CO}_{3}$. The white precipitate formed was collected, washed with an aqueous solution of $\mathrm{Na}_{2} \mathrm{CO}_{3}$, and dried in vacuo. The raw product was further purified by column chromatography, using a 7:1:0.15 $\mathrm{CHCl}_{3} / \mathrm{CH}_{3} \mathrm{OH} /$ concentrated $\mathrm{NH}_{4} \mathrm{OH}$ mixture. Yield: $463 \mathrm{mg}, 91 \%$. Anal. 
calcd. for $\mathrm{C}_{19} \mathrm{H}_{20} \mathrm{~N}_{4} \cdot 0.25 \mathrm{H}_{2} \mathrm{O}\left(M_{\mathrm{r}} 308.89\right)$ : C, 73.88; H, 6.62 ; N, 18.14\%. Found: C, 73.65; H, 6.33; N, $17.95 \%$. Solubility in DMSO: $945 \mathrm{mM}$ or greater. Solubility in $1 \%$ DMSO/PBS: $275 \mu \mathrm{M}$ or greater.

\section{$N-(7,12-D i h y d r o i n d o l o[3,2-d][1]$ benzazepin-6-yl)-ethane- 1,2-diamine $\left(\boldsymbol{L}^{3}\right)$}

A mixture of 7,12-dihydroindolo[3,2- $d]$ [1] benzazepin$6(5 H)$-thione $(500 \mathrm{mg}, 1.89 \mathrm{mmol})$ and ethane-1,2-diamine $(1.26 \mathrm{~mL}, 18.90 \mathrm{mmol})$ in dry THF $(30 \mathrm{~mL})$ was refluxed under light protection and an argon atmosphere for $24 \mathrm{~h}$. After the mixture had been cooled to room temperature, it was filtered, the solvent was evaporated to dryness, and the oily residue was suspended in water to yield a white precipitate. The latter was filtered off and dissolved in diethyl ether $(80 \mathrm{~mL})$. Half of the solvent was removed under reduced pressure, and the remaining solution was allowed to stand at $-20{ }^{\circ} \mathrm{C}$ for crystallization. After 3 days the precipitate was collected under suction, washed with a small amount of cold diethyl ether $(5 \mathrm{~mL})$, and dried in vacuo. Yield: $272 \mathrm{mg}, 50 \%$. Anal. calcd. for $\mathrm{C}_{18} \mathrm{H}_{18} \mathrm{~N}_{4} \cdot 0.4 \mathrm{H}_{2} \mathrm{O}\left(M_{\mathrm{r}}\right.$ 297.57): C, 72.65; H, 6.37; N, 18.83\%. Found: C, 72.88; H, 6.01 ; N, $18.40 \%$. Solubility in DMSO: $197 \mathrm{mM}$ or greater. Solubility in $1 \%$ DMSO/PBS: $225 \mu \mathrm{M}$ or greater.

\section{$N^{\prime}-(7,12-D i h y d r o i n d o l o[3,2-d][1]$ benzazepin-6-yl)-N,N- dimethylethane-1,2-diamine $\left(\boldsymbol{L}^{4}\right)$}

A mixture of 7,12-dihydroindolo[3,2-d][1]benzazepin$6(5 H)$-thione $(2.00 \mathrm{~g}, 7.57 \mathrm{mmol})$ and $N, N$-dimethylethane-1,2-diamine $(1.50 \mathrm{~mL}, 13.73 \mathrm{mmol})$ in dry THF $(120 \mathrm{~mL})$ was refluxed at $80{ }^{\circ} \mathrm{C}$ for $26 \mathrm{~h}$ under an argon atmosphere. After filtration the solvent was evaporated to dryness. The residue was suspended in hexane $(10 \mathrm{~mL})$, filtered off, and dissolved in diethyl ether $(150 \mathrm{~mL})$. About half of the solvent was removed under reduced pressure, and the remaining solution was allowed to stand at $-20{ }^{\circ} \mathrm{C}$ for crystallization. After 3 days the precipitate was filtered off, washed with cold diethyl ether, and dried in vacuo. Yield: $1.74 \mathrm{~g}, \quad 72 \%$. Anal. calcd. for $\mathrm{C}_{20} \mathrm{H}_{22} \mathrm{~N}_{4} \cdot 0.20 \mathrm{H}_{2} \mathrm{O}$ ( $M_{\mathrm{r}}$ 322.02): C, 74.60; H, 7.01; N, 17.40\%. Found: C, 74.58; $\mathrm{H}, 6.75$; N, $17.13 \%$. Solubility in DMSO: $885 \mathrm{mM}$ or greater. Solubility in $1 \%$ DMSO/PBS: $380 \mu \mathrm{M}$ or greater.

$\left[\left(\eta^{6}-p\right.\right.$-Cymene $\left.) \mathrm{Ru}^{I I}\left(\boldsymbol{L}^{\mathbf{1}}\right) \mathrm{Cl}\right] \mathrm{Cl},\left(\eta^{6}-p\right.$-cymene $)$ $\left(\kappa N\right.$-[11H-indolo[3,2-c]quinolin-6-ylidene]- $\kappa N^{\prime}$-ethane-1, 2-diamine)chloridoruthenium(II) chloride (4)

A mixture of $\left[\mathrm{Ru}^{\mathrm{II}} \mathrm{Cl}(\mu-\mathrm{Cl})\left(\eta^{6}-p \text {-cymene }\right)\right]_{2} \quad(111 \mathrm{mg}$, $0.18 \mathrm{mmol}$ ) and $\mathbf{L}^{\mathbf{1}}$ (100 $\left.\mathrm{mg}, 0.36 \mathrm{mmol}\right)$ in dry ethanol $(2.5 \mathrm{~mL})$ was stirred under an argon atmosphere for $24 \mathrm{~h}$. The orange precipitate was filtered off, washed with cold ethanol (1.5 mL), and dried in vacuo. Yield: $193 \mathrm{mg}, 91 \%$. Anal. calcd. for $\mathrm{C}_{27} \mathrm{H}_{30} \mathrm{~N}_{4} \mathrm{Cl}_{2} \mathrm{Ru} \cdot \mathrm{H}_{2} \mathrm{O}\left(M_{\mathrm{r}}\right.$ 600.54): $\mathrm{C}$, 54.00; H, 5.37; N, 9.33\%. Found: C, 53.78; H, 5.29; N, $9.05 \%$. Solubility in DMSO: $228 \mathrm{mM}$ or greater. X-ray diffraction quality crystals were obtained by slow evaporation of a solution of $\mathbf{4}$ in 1:3 methanol/diethyl ether.

$\left[\left(\eta^{6}-p\right.\right.$-Cymene $\left.) R u^{I I}\left(\boldsymbol{L}^{2}\right) \mathrm{Cl}\right] \mathrm{Cl},\left(\eta^{6}-p\right.$-cymene $)\left(\kappa N^{\prime}-[11 \mathrm{H}\right.$ indolo[3,2-c]quinolin-6-ylidene]- $\kappa N, N$-dimethylethane1,2-diamine)chloridoruthenium(II) chloride (5)

A mixture of $\left[\mathrm{Ru}^{\mathrm{II}} \mathrm{Cl}(\mu-\mathrm{Cl})\left(\eta^{6}-p \text {-cymene }\right)\right]_{2} \quad(101 \mathrm{mg}$, $0.16 \mathrm{mmol})$ and $\mathbf{L}^{\mathbf{2}}(100 \mathrm{mg}, 0.33 \mathrm{mmol})$ in dry ethanol $(2.3 \mathrm{~mL})$ was stirred under an argon atmosphere at room temperature for $23 \mathrm{~h}$. The orange precipitate formed was filtered off, washed with ethanol $(1.5 \mathrm{~mL})$, and dried in vacuo for $48 \mathrm{~h}$. Yield: $141 \mathrm{mg}, 70 \%$. Anal. calcd. for $\mathrm{C}_{29} \mathrm{H}_{34} \mathrm{~N}_{4} \mathrm{Cl}_{2} \mathrm{Ru}\left(M_{\mathrm{r}} 610.58\right)$ : C, 57.04; H, 5.61, N, 9.18\%. Found: C, 57.13; H, 5.41; N, 9.18\%. Solubility in DMSO: $21 \mathrm{mM}$ or greater. Solubility in $1 \%$ DMSO/PBS: $210 \mu \mathrm{M}$ or greater. Single crystals suitable for X-ray diffraction study were obtained by slow diffusion of diethyl ether into the solution of the complex in ethanol.

$\left[\left(\eta^{6}\right.\right.$-p-Cymene $\left.) \mathrm{Os}^{I I}\left(\boldsymbol{L}^{1}\right) \mathrm{Cl}\right] \mathrm{Cl},\left(\eta^{6}-p\right.$-cymene $)(\kappa N-[11 \mathrm{H}$ indolo[3,2-c]quinolin-6-ylidene $]-\kappa N^{\prime}$-ethane-1,2-diamine) chloridoosmium(II) chloride (6)

A mixture of $\left[\mathrm{Os}^{\mathrm{II}} \mathrm{Cl}(\mu-\mathrm{Cl})\right)\left(\eta^{6}-p\right.$-cymene $\left.)\right]_{2} \quad(87 \mathrm{mg}$, $0.11 \mathrm{mmol})$ and $\mathbf{L}^{\mathbf{1}}(61 \mathrm{mg}, 0.22 \mathrm{mmol})$ in dry ethanol $(1.8 \mathrm{~mL})$ was stirred under light protection and an argon atmosphere at room temperature for $23 \mathrm{~h}$. The yellow precipitate formed was filtered off, washed with cold ethanol (1.5 mL), and dried in vacuo. Yield: $100 \mathrm{mg}, 68 \%$. Anal. calcd. for $\mathrm{C}_{27} \mathrm{H}_{30} \mathrm{~N}_{4} \mathrm{Cl}_{2} \mathrm{Os} \cdot 0.5 \mathrm{H}_{2} \mathrm{O}\left(M_{\mathrm{r}}\right.$ 680.70): $\mathrm{C}$, 47.64; H, 4.59; N, 8.32\%. Found: C, 47.87; H, 4.55; N, 8.31\%. Solubility in DMSO: $235 \mathrm{mM}$ or greater. Solubility in $1 \% \mathrm{DMSO} / \mathrm{PBS}: 260 \mu \mathrm{M}$ or greater.

$\left[\left(\eta^{6}-p-C y m e n e\right) O s^{I I}\left(\boldsymbol{L}^{2}\right) \mathrm{Cl}\right] \mathrm{Cl},\left(\eta^{6}-p\right.$-cymene $)\left(\kappa N^{\prime}-[11 \mathrm{H}-\right.$ indolo[3,2-c]quinolin-6-ylidene]- $\kappa N, N$-dimethylethane1,2-diamine)chloridoosmium(II) chloride (7)

A mixture of $\left[\mathrm{Os}{ }^{\mathrm{II}} \mathrm{Cl}(\mu-\mathrm{Cl})\left(\eta^{6}-p \text {-cymene }\right)\right]_{2} \quad(130 \mathrm{mg}$, $0.16 \mathrm{mmol})$ and $\mathbf{L}^{\mathbf{2}}(100 \mathrm{mg}, 0.33 \mathrm{mmol})$ in dry ethanol $(2.3 \mathrm{~mL})$ was stirred under light protection and an argon atmosphere at room temperature for $23 \mathrm{~h}$. The yellow precipitate formed was filtered off, washed with ethanol $(0.5 \mathrm{~mL})$, and dried in vacuo. Yield: $147 \mathrm{mg}, 64 \%$. Anal. calcd. for $\mathrm{C}_{29} \mathrm{H}_{34} \mathrm{~N}_{4} \mathrm{Cl}_{2} \mathrm{Os} \cdot 0.5 \mathrm{H}_{2} \mathrm{O}\left(M_{\mathrm{r}} 708.75\right)$ : C, 49.14; H, 4.98; N, 7.91\%. Found: C, 49.03; H, 4.70; N, 7.74\%. Solubility in DMSO: $23 \mathrm{mM}$ or greater. Solubility in 1\% DMSO/PBS: $230 \mu \mathrm{M}$ or greater. 
$\left[\left(\eta^{6}-p\right.\right.$-Cymene $\left.) R u^{I I}\left(\mathbf{L}^{3}\right) C l\right] C l,\left(\eta^{6}-p\right.$-cymene $)(\kappa N-[7,12-$ dihydroindolo[3,2-d][1]benzazepin-6-ylidene $]-\kappa N^{\prime}$-ethane1,2-diamine)chloridoruthenium(II) chloride (8)

A mixture of $\left[\mathrm{Ru}^{\mathrm{II}} \mathrm{Cl}(\mu-\mathrm{Cl})\left(\eta^{6}-p \text {-cymene }\right)\right]_{2} \quad(127 \mathrm{mg}$, $0.21 \mathrm{mmol})$ and $\mathbf{L}^{\mathbf{3}}(120 \mathrm{mg}, 0.41 \mathrm{mmol})$ in dry ethanol (4 mL) was stirred under an argon atmosphere at $50{ }^{\circ} \mathrm{C}$ for $4 \mathrm{~h}$. After the reaction mixture had been cooled to room temperature, the product was precipitated by addition of diethyl ether $(25 \mathrm{~mL})$, filtered off, washed with diethyl ether $(2 \times 5 \mathrm{~mL})$, and dried at $60^{\circ} \mathrm{C}$ in vacuo. Yield: $193 \mathrm{mg}, 78 \%$. Anal. calcd. for $\mathrm{C}_{28} \mathrm{H}_{32} \mathrm{~N}_{4} \mathrm{Cl}_{2} \mathrm{Ru} \cdot 1.25 \mathrm{H}_{2} \mathrm{O}$ $\left(M_{\mathrm{r}} 619.08\right): \quad \mathrm{C}, 54.32 ; \quad \mathrm{H}, 5.62 ; \quad \mathrm{N}, 9.05 \%$. Found: C, 54.30; H, 5.31; N, 8.93\%. Solubility in DMSO: $246 \mathrm{mM}$ or greater. Solubility in 1\% DMSO/PBS: $315 \mu \mathrm{M}$ or greater.

$\left[\left(\eta^{6}-p\right.\right.$-Cymene $\left.) R u^{I I}\left(\boldsymbol{L}^{4}\right) \mathrm{Cl}\right] \mathrm{Cl},\left(\eta^{6}\right.$-p-cymene $)\left(\kappa N^{\prime}-[7,12-\right.$ dihydroindolo[3,2-d][1]benzazepin-6-ylidene]- $\kappa N, N$ dimethylethane-1,2-diamine)chloridoruthenium(II) chloride (9)

A mixture of $\mathbf{L}^{4}(50 \mathrm{mg}, 0.16 \mathrm{mmol})$ and $\left[\mathrm{Ru}{ }^{\mathrm{II}} \mathrm{Cl}(\mu-\mathrm{Cl})\left(\eta^{6}-\right.\right.$ $p$-cymene $)]_{2}(48 \mathrm{mg}, 0.08 \mathrm{mmol})$ in dry ethanol $(2.3 \mathrm{~mL})$ was stirred under an argon atmosphere at $50{ }^{\circ} \mathrm{C}$ for $4.4 \mathrm{~h}$. After cooling to room temperature, by slow diffusion of diethyl ether into the red-brown solution the orange product crystallized. The crystals were separated and dried in vacuo. Yield: $90 \mathrm{mg}, 92 \%$. Anal. calcd. for $\mathrm{C}_{30} \mathrm{H}_{36} \mathrm{~N}_{4} \mathrm{Cl}_{2} \mathrm{Ru} \cdot \mathrm{H}_{2} \mathrm{O} \quad\left(M_{\mathrm{r}} 642.60\right): \quad \mathrm{C}, 56.07 ; \quad \mathrm{H}$ 5.96; N, $8.72 \%$. Found: C, $56.21 ; \mathrm{H}, 6.02 ; \mathrm{N}, 8.56 \%$. Solubility in DMSO: $189 \mathrm{mM}$ or greater. Solubility in $1 \% \mathrm{DMSO} /$ PBS: $465 \mu \mathrm{M}$ or greater. Crystals suitable for X-ray diffraction study were obtained by slow diffusion of diethyl ether into the reaction mixture.

$\left[\left(\eta^{6}-p\right.\right.$-Cymene $\left.) O s^{I I}\left(\boldsymbol{L}^{3}\right) \mathrm{Cl}\right] \mathrm{Cl},\left(\eta^{6}-p\right.$-cymene $)(\kappa N-[7,12-$ dihydroindolo[3,2-d][1]benzazepin-6-ylidene]- $\kappa N^{\prime}$-ethane1,2-diamine)chloridoosmium(II) chloride (10)

A mixture of $\left[\mathrm{Os}^{\mathrm{II}} \mathrm{Cl}(\mu-\mathrm{Cl})\left(\eta^{6}-p \text {-cymene }\right)\right]_{2} \quad(137 \mathrm{mg}$, $0.17 \mathrm{mmol})$ and $\mathbf{L}^{\mathbf{3}}(100 \mathrm{mg}, 0.35 \mathrm{mmol})$ in dry ethanol $(4 \mathrm{~mL})$ was stirred under an argon atmosphere at $50{ }^{\circ} \mathrm{C}$ for $4 \mathrm{~h}$. After the reaction mixture had been cooled to room temperature, the product was precipitated by addition of diethyl ether $(25 \mathrm{~mL})$, filtered off, washed with diethyl ether $(3 \times 5 \mathrm{~mL})$, and dried at $60{ }^{\circ} \mathrm{C}$ in vacuo. Yield: $159 \mathrm{mg}$, 67\%. Anal. calcd. for $\mathrm{C}_{28} \mathrm{H}_{32} \mathrm{~N}_{4} \mathrm{Cl}_{2} \mathrm{Os} \cdot \mathrm{H}_{2} \mathrm{O}$ $\left(M_{\mathrm{r}} 703.73\right)$ : C, 47.79; H, 4.87; N, 7.96\%. Found: C, 47.86; H, 4.58; N, 8.02\%. Solubility in DMSO: $235 \mathrm{mM}$ or greater. Solubility in 1\% DMSO/PBS: $110 \mu \mathrm{M}$ or greater. $\left[\left(\eta^{6}-\right.\right.$ - -Cymene $\left.) O s^{I I}\left(\mathbf{L}^{4}\right) \mathrm{Cl}\right] \mathrm{Cl},\left(\eta^{6}-\right.$ p-cymene $)\left(\kappa N^{\prime}-[7\right.$, 12-dihydroindolo[3,2-d][1]benzazepin-6-ylidene]- $\kappa N, N$ dimethylethane-1,2-diamine)chloridooosmium(II) chloride (11)

A mixture of $\left[\mathrm{Os}{ }^{\mathrm{II}} \mathrm{Cl}(\mu-\mathrm{Cl})\left(\eta^{6}-p \text {-cymene }\right)\right]_{2} \quad(124 \mathrm{mg}$, $0.157 \mathrm{mmol})$ and $\mathbf{L}^{4}(100 \mathrm{mg}, 0.31 \mathrm{mmol})$ in dry ethanol $(4 \mathrm{~mL})$ was stirred under light protection and an inert atmosphere at $50{ }^{\circ} \mathrm{C}$ for $4 \mathrm{~h}$. After the solution had been cooled to room temperature, diethyl ether $(20 \mathrm{~mL})$ was added to precipitate the product. The yellow powder was collected by filtration, washed with diethyl ether $(2 \times 8 \mathrm{~mL})$, and dried in vacuo at $60{ }^{\circ} \mathrm{C}$. Yield: $182 \mathrm{mg}$, 81\%. Anal. calcd. for $\mathrm{C}_{30} \mathrm{H}_{36} \mathrm{~N}_{4} \mathrm{Cl}_{2} \mathrm{Os} \cdot \mathrm{H}_{2} \mathrm{O}\left(M_{\mathrm{r}} 731.78\right)$ : C, 49.24; H, 5.23; N, 7.66. Found: C, 49.02; H, 5.23; $\mathrm{N}, 7.52 \%$. Solubility in DMSO: $167 \mathrm{mM}$ or greater. Solubility in $1 \% \mathrm{DMSO} / \mathrm{PBS}$ : $460 \mu \mathrm{M}$ or greater. Single crystals of X-ray diffraction quality were grown by slow diffusion of diethyl ether into an ethanolic solution of the complex. The complex was found to be isostructural with its ruthenium analogue 9, crystallizing in the monoclinic space group $P 2{ }_{1} / n$ with the following cell parameters: $a=$ 12.9857(11) $\mathrm{A}, \quad b=19.2791(17) \AA, c=13.2419(10) \AA$, and $\beta=109.589(5)^{\circ}$.

\section{Physical measurements}

One-dimensional ${ }^{1} \mathrm{H}$ and ${ }^{13} \mathrm{C}$ NMR and two-dimensional ${ }^{1} \mathrm{H}-{ }^{1} \mathrm{H}$ correlation spectroscopy, ${ }^{1} \mathrm{H}-{ }^{1} \mathrm{H}$ total correlation spectroscopy, ${ }^{1} \mathrm{H}-{ }^{1} \mathrm{H}$ rotating frame Overhauser enhancement spectroscopy or ${ }^{1} \mathrm{H}-{ }^{1} \mathrm{H}$ nuclear Overhauser enhancement spectroscopy, ${ }^{1} \mathrm{H}-{ }^{13} \mathrm{C}$ heteronuclear single quantum coherence, and ${ }^{1} \mathrm{H}-{ }^{13} \mathrm{C}$ heteronuclear multiple bond correlation NMR spectra were recorded using two Bruker Avance III spectrometers at 500.32 or $500.10 \mathrm{MHz}\left({ }^{1} \mathrm{H}\right)$ and 125.82 or $125.76\left({ }^{13} \mathrm{C}\right) \mathrm{MHz}$, respectively, by using as a solvent DMSO- $d_{6}$ or MeOD- $d_{4}$ at room temperature and standard pulse programs. ${ }^{1} \mathrm{H}$ and ${ }^{13} \mathrm{C}$ shifts are quoted relative to the solvent residual signals. The atom numbering used for assignments is depicted in Scheme S3. IR spectra were measured with a Bruker Vertex 70 Fourier transform IR spectrometer by means of the attenuated total reflection technique, and UV-vis spectra were recorded with a PerkinElmer Lambda 650 spectrophotometer. Shoulders were evaluated by using the first derivatives of the spectra. Electrospray ionization (ESI) mass spectrometry was carried out with a Bruker Esquire 3000 instrument; the samples were dissolved in methanol. Thermogravimetric analysis (TGA) and differential thermal analysis (DTA) were carried out with a Mettler Toledo TGA/SDTA $851^{\mathrm{e}}$ instrument. The substances were flushed with nitrogen $(50 \mathrm{~mL} / \mathrm{min})$ at $25{ }^{\circ} \mathrm{C}$ for $30 \mathrm{~min}$ and then heated to $700{ }^{\circ} \mathrm{C}$ in a nitrogen stream $(50 \mathrm{~mL} / \mathrm{min})$, with a heating rate of $5{ }^{\circ} \mathrm{C} / \mathrm{min}$. All 
elemental analyses were performed at the Microanalytical Laboratory of the University of Vienna with a PerkinElmer 2400 CHN elemental analyzer.

Crystallographic structure determination

X-ray diffraction measurements were performed using a Bruker X8 APEXII CCD diffractometer. Single crystals were positioned at $35,35,40$, and $40 \mathrm{~mm}$ from the detector, and 1,066, 2,768, 1,705, and 1,451 frames were measured, each for $120,20,80$, and $40 \mathrm{~s}$ over $1^{\circ}$ scan width for $\mathbf{L}^{\mathbf{1}} \cdot \mathrm{HCl}, \mathbf{4} \cdot \mathrm{H}_{2} \mathrm{O}, \mathbf{5}$, and $\mathbf{9} \cdot 2.5 \mathrm{H}_{2} \mathrm{O}$, respectively. The data were processed using SAINT Plus [38]. Crystal data, data collection parameters, and structure refinement details are given in Table 1. The structures were solved by direct methods and refined by full-matrix least-squares techniques. Non-hydrogen atoms were refined with anisotropic displacement parameters. Hydrogen atoms were inserted in calculated positions and refined with a riding model. The following software programs, computer, and tables were used: SHELXS-97 for structure solution [39]; SHELXL-97 for refinement [40]; ORTEP for molecular diagrams [41]; a Pentium IV computer; Tables 4.2.6.8 and 6.1.1.4 in [42] for scattering factors.
Cell lines and culture conditions

CH1 (ovarian carcinoma, human) cells were donated by Lloyd R. Kelland (CRC Centre for Cancer Therapeutics, Institute of Cancer Research, Sutton, UK). SW480 (colon adenocarcinoma, human) cells and A549 (non-small cell lung cancer, human) cells were kindly provided by Brigitte Marian (Institute of Cancer Research, Department of Medicine I, Medical University of Vienna, Austria). Cells were grown without antibiotics in $75-\mathrm{cm}^{2}$ culture flasks (Iwaki/Asahi Technoglass) as adherent monolayer cultures in minimal essential medium supplemented with $10 \%$ heatinactivated fetal bovine serum, $1 \mathrm{mM}$ sodium pyruvate, and $2 \mathrm{mM}$ L-glutamine (all purchased from SigmaAldrich). Cultures were maintained at $37{ }^{\circ} \mathrm{C}$ in a humidified atmosphere containing $5 \% \mathrm{CO}_{2}$ and $95 \%$ air.

Cytotoxicity in cancer cell lines

Cytotoxicity in the cell lines mentioned in the previous section was determined by the colorimetric 3-(4,5-dimethyl2-thiazolyl)-2,5-diphenyl-2H-tetrazolium bromide (MTT; purchased from Sigma-Aldrich) assay. For this purpose, cells were harvested from culture flasks by trypsinization

Table 1 Crystal data and details of data collection for $\mathbf{L}^{\mathbf{1}} \cdot \mathrm{HCl}, \mathbf{4} \cdot \mathrm{H}_{2} \mathrm{O}, \mathbf{5}$, and $\mathbf{9} \cdot 2.5 \mathrm{H}_{2} \mathrm{O}$

\begin{tabular}{|c|c|c|c|c|}
\hline & $\mathbf{L}^{\mathbf{1}} \cdot \mathrm{HCl}$ & $4 \cdot \mathrm{H}_{2} \mathrm{O}$ & 5 & 9. $2.5 \mathrm{H}_{2} \mathrm{O}$ \\
\hline Empirical formula & $\mathrm{C}_{17} \mathrm{H}_{17} \mathrm{ClN}_{4}$ & $\mathrm{C}_{27} \mathrm{H}_{32} \mathrm{Cl}_{2} \mathrm{~N}_{4} \mathrm{ORu}$ & $\mathrm{C}_{29} \mathrm{H}_{34} \mathrm{Cl}_{2} \mathrm{~N}_{4} \mathrm{Ru}$ & $\mathrm{C}_{30} \mathrm{H}_{41} \mathrm{Cl}_{2} \mathrm{~N}_{4} \mathrm{O}_{2.5} \mathrm{Ru}$ \\
\hline Formula weight & 312.80 & 600.54 & 610.57 & 669.65 \\
\hline Space group & Pnma & $P 2_{1} / c$ & $P 2_{1} / n$ & $P 2_{1} / n$ \\
\hline$a(\AA)$ & $19.552(2)$ & $11.2077(4)$ & $10.7821(6)$ & $12.9729(7)$ \\
\hline$b(\AA)$ & $6.5845(12)$ & $15.5943(5)$ & $20.7288(12)$ & $19.1797(11)$ \\
\hline$c(\AA)$ & $11.6690(18)$ & $15.5918(5)$ & $12.0944(7)$ & $13.1560(6)$ \\
\hline$\beta\left(^{\circ}\right)$ & & $103.277(2)$ & $93.834(4)$ & 109.911(3) \\
\hline$V\left(\AA^{3}\right)$ & $1,502.3(4)$ & $2,652.24(15)$ & $2,697.0(3)$ & $3,077.8(3)$ \\
\hline$Z$ & 4 & 4 & 4 & 4 \\
\hline$\lambda(\AA)$ & 0.71073 & 0.71073 & 0.71073 & 0.71073 \\
\hline$\rho_{\text {calcd }}\left(\mathrm{g} \mathrm{cm}^{-3}\right)$ & 1.383 & 1.504 & 1.504 & 1.445 \\
\hline Crystal size $\left(\mathrm{mm}^{3}\right)$ & $0.20 \times 0.04 \times 0.04$ & $0.20 \times 0.20 \times 0.15$ & $0.13 \times 0.10 \times 0.03$ & $0.12 \times 0.12 \times 0.10$ \\
\hline$T(\mathrm{~K})$ & 100 & 100 & 296 & 100 \\
\hline$\mu\left(\mathrm{mm}^{-1}\right)$ & 0.256 & 0.820 & 0.805 & 0.718 \\
\hline$R_{1}^{\mathrm{a}}$ & 0.0894 & 0.0279 & 0.0425 & 0.0414 \\
\hline$w R_{2}^{\mathrm{b}}$ & 0.2049 & 0.0652 & 0.0965 & 0.0993 \\
\hline $\mathrm{GOF}^{\mathrm{c}}$ & 1.015 & 1.014 & 0.956 & 1.031 \\
\hline
\end{tabular}

GOF goodness of fit

${ }^{\mathrm{a}} R_{1}=\Sigma\left\|F_{\mathrm{o}}|-| F_{\mathrm{c}}\right\| / \Sigma \mid F_{\mathrm{o}} \mathrm{l}$

b $w R_{2}=\left\{\Sigma\left[w\left(F_{\mathrm{o}}^{2}-F_{\mathrm{c}}^{2}\right)^{2}\right] / \Sigma\left[w\left(F_{\mathrm{o}}^{2}\right)^{2}\right]\right\}^{1 / 2}$

${ }^{\mathrm{c}} \mathrm{GOF}=\left\{\Sigma\left[w\left(F_{\mathrm{o}}^{2}-F_{\mathrm{c}}^{2}\right)^{2}\right] /(n-p)\right\}^{1 / 2}$, where $n$ is the number of reflections and $p$ is the total number of parameters refined 
and seeded in $100-\mu \mathrm{L}$ aliquots in minimal essential medium supplemented with $10 \%$ heat-inactivated fetal bovine serum, $1 \mathrm{mM}$ sodium pyruvate, $4 \mathrm{mM}$ L-glutamine, and $1 \%$ nonessential amino acids $(100 \times)$ (all purchased from Sigma-Aldrich) into 96-well microculture plates (Iwaki/ Asahi Technoglass). The following cell densities were chosen, to ensure exponential growth of untreated controls throughout the experiment: $1.5 \times 10^{3}(\mathrm{CH} 1), 2.5 \times 10^{3}$ (SW480), and $4.0 \times 10^{3}$ (A549) viable cells per well. For $24 \mathrm{~h}$, cells were allowed to settle and resume exponential growth, followed by the addition of dilutions of the test compounds in aliquots of $100 \mu \mathrm{L}$ per well in the same medium. After continuous exposure for $96 \mathrm{~h}$, the medium was replaced by $100 \mu \mathrm{L}$ RPMI 1640 medium (supplemented with $10 \%$ heat-inactivated fetal bovine serum and $4 \mathrm{mM}$ L-glutamine) per well plus a $20 \mu \mathrm{L}$ per well solution of MTT in PBS $(5 \mathrm{mg} / \mathrm{mL}$ ) (all purchased from SigmaAldrich). After incubation for $4 \mathrm{~h}$, medium/MTT mixtures were removed, and the formazan product formed by viable cells was dissolved in DMSO (150 $\mu \mathrm{L}$ per well). Optical densities at $550 \mathrm{~nm}$ were measured with a microplate reader (Tecan Spectra Classic), using a reference wavelength of $690 \mathrm{~nm}$ to correct for unspecific absorption. The quantity of viable cells was expressed as the percentage of untreated controls, and 50\% inhibitory concentrations $\left(\mathrm{IC}_{50}\right)$ were calculated from concentration-effect curves by interpolation. Evaluation was based on at least three independent experiments, each comprising three replicates per concentration.

\section{DNA intercalation}

The capacity of the test compounds to intercalate into salmon sperm DNA was determined by the methyl green assay [43] with minor modifications as described previously [44]. Briefly, salmon sperm DNA $(10 \mathrm{mg} / \mathrm{mL})$ was incubated for $1 \mathrm{~h}$ at $37^{\circ} \mathrm{C}$ with $32 \mu \mathrm{M}$ methyl green. Reduction of the absorbance of methyl green at $642 \mathrm{~nm}$ induced by the test compounds after incubation for $2 \mathrm{~h}$ at $37{ }^{\circ} \mathrm{C}$ was measured with a fluorescence reader (Bio-Tek Synergy HT).

\section{Kinase assay}

The activities of recombinant cdk1/cyclin B and cdk2/ cyclin $\mathrm{E}$ expressed in and isolated from $\mathrm{Sf} 21$ insect cells were determined by a modified radioassay [45], using histone $\mathrm{H} 1$ as the substrate for phosphorylation. Briefly, assay mixtures containing the test compound (except for untreated controls), the respective kinase/cyclin complex, histone $\mathrm{H} 1$, and $0.4 \mu \mathrm{Ci}\left(\gamma-{ }^{32} \mathrm{P}\right) \mathrm{ATP}$ per sample were incubated for $10 \mathrm{~min}$ at $30{ }^{\circ} \mathrm{C}$. Aliquots of the solution were spotted onto phosphocellulose squares, which had been washed three times with $0.75 \%$ phosphoric acid followed by acetone. The dried squares were measured in scintillation vials by $\beta$-counting (PerkinElmer Tri-Carb 2800TR; software program Quanta Smart). Results were obtained in duplicates in at least two independent experiments, and $\mathrm{IC}_{50}$ values were calculated by interpolation.

\section{Cell cycle analyses}

One million A549 cells were seeded into Petri dishes and allowed to recover for $24 \mathrm{~h}$. Cells were then exposed for $24 \mathrm{~h}$ to the test compounds. Control and treated cells were collected, washed with PBS, fixed in 70\% ice-cold ethanol, and stored at $-20{ }^{\circ} \mathrm{C}$. To determine cell cycle distributions, cells were transferred in physiological $\mathrm{NaCl}$ solution into PBS, incubated with $10 \mu \mathrm{g} / \mathrm{mL}$ RNase A for $30 \mathrm{~min}$ at $37{ }^{\circ} \mathrm{C}$, followed by treatment with $5 \mu \mathrm{g} / \mathrm{mL}$ propidium iodide for $30 \mathrm{~min}$, and their fluorescence was measured by flow cytometry, using a FACSCalibur instrument (Becton Dickinson, Palo Alto, CA, USA). The resulting DNA histograms were quantified by Cell Quest Pro (Becton Dickinson, New York, NY, USA).

\section{Results and discussion}

Synthesis and characterization of ligands and metal complexes

Compound $\mathbf{L}^{\mathbf{1}}$ was prepared by reaction of 6-chloro- $11 \mathrm{H}$ indolo[3,2-c] quinoline with 10 equiv of ethane-1,2-diamine in 1-butanol at $132{ }^{\circ} \mathrm{C}$ for $26 \mathrm{~h}$ under an argon atmosphere in $85 \%$ yield. A large excess of ethane-1,2-diamine was used to avoid formation of a $2: 1$ condensation product of 6-chloro-11H-indolo[3,2-c]quinoline with ethane-1,2-diamine (Scheme $\mathrm{S} 1$ ). The synthesis of $\mathbf{L}^{2}$ was realized in a similar way by using a twofold excess of $N, N$-dimethylethane-1,2-diamine in 91\% yield (Scheme S1). It should, however, be noted that the synthesis of $\mathbf{L}^{\mathbf{2}}$ is well documented in the literature [25]. Compounds $\mathbf{L}^{\mathbf{3}}$ and $\mathbf{L}^{\mathbf{4}}$ were synthesized by reacting thiolactam 7,12-dihydroindolo[3,2- $d]$ [1]benzazepin-6 $(5 H)$-thione [35] with 10 equiv of ethane-1,2diamine and 1.9 equiv of $\mathrm{N}, \mathrm{N}$-dimethylethane-1,2-diamine, respectively, in dry $\mathrm{THF}$ at $80{ }^{\circ} \mathrm{C}$ for $26 \mathrm{~h}$ under an argon atmosphere (Scheme S2).

Ruthenium(II) and osmium(II) complexes 4-11 were prepared in $64-91 \%$ yield by following a conventional protocol of a bridge splitting reaction of dimeric starting material $\left[\left(\eta^{6}-p \text {-cymene }\right) \mathrm{M}^{\mathrm{II}}(\mu-\mathrm{Cl}) \mathrm{Cl}\right]_{2}(\mathrm{M}$ is $\mathrm{Ru}, \mathrm{Os})$ with ligands $\mathbf{L}^{\mathbf{1}}-\mathbf{L}^{\mathbf{4}}$ in dry ethanol.

The positive ion ESI mass spectra of $\mathbf{L}^{\mathbf{1}}-\mathbf{L}^{\mathbf{4}}$ show the presence of peaks at $\mathrm{m} / \mathrm{z} 277,305,291$, and 319 , attributable to $\left[\mathbf{L}^{\mathbf{1}}+\mathrm{H}\right]^{+},\left[\mathbf{L}^{\mathbf{2}}+\mathrm{H}\right]^{+},\left[\mathbf{L}^{\mathbf{3}}+\mathrm{H}\right]^{+}$, and $\left[\mathbf{L}^{\mathbf{4}}+\mathrm{H}\right]^{+}$, 
respectively. In addition, peaks at $\mathrm{m} / \mathrm{z} 327$ and 260 for $\mathbf{L}^{2}$ and $m / z, 341$ and 274 for $\mathbf{L}^{\mathbf{4}}$ were assigned to $[\mathrm{M}+\mathrm{Na}]^{+}$ and $\left[\mathrm{M}-\mathrm{N}\left(\mathrm{CH}_{3}\right)_{2}\right]^{+}$, where $\mathrm{M}$ is the molecular ion, respectively. For 4 and $\mathbf{6}$, the complex cations $\left[\left(\eta^{6}-p-\right.\right.$ cymene $\left.) \mathrm{Ru}^{\mathrm{II}}\left(\mathbf{L}^{\mathbf{1}}\right) \mathrm{Cl}\right]^{+}$and $\left[\left(\eta^{6}-p \text {-cymene }\right) \mathrm{Os}^{\mathrm{II}}\left(\mathbf{L}^{\mathbf{1}}\right) \mathrm{Cl}\right]^{+}$ display moderate peaks at $m / z 547$ and 637, respectively. However, the strongest are the signals at $\mathrm{m} / \mathrm{z} 511$ and 601 , attributed to $\left[\left(\eta^{6}-p \text {-cymene }\right) \mathrm{M}^{\mathrm{II}}\left(\mathbf{L}^{\mathbf{1}}\right)-\mathrm{HCl}\right]^{+}$, where $\mathrm{M}^{\mathrm{II}}$ is $\mathrm{Ru}^{\mathrm{II}}$ and $\mathrm{Os}^{\mathrm{II}}$. A peak of low relative intensity at $m / z$ 277 in $\mathbf{4}$ is due to $\left[\mathbf{L}^{\mathbf{1}}+\mathbf{H}\right]^{+}$. Strong peaks at $m / z, 539$ and 629 in the mass spectra of 5 and 7 were attributed to $\left[\left(\eta^{6}-p\right.\right.$ cymene) $\left.\mathrm{M}^{\mathrm{II}}\left(\mathbf{L}^{\mathbf{2}}\right)-\mathrm{HCl}\right]^{+}$, where $\mathrm{M}^{\mathrm{II}}$ is $\mathrm{Ru}^{\mathrm{II}}$ and $\mathrm{Os}^{\mathrm{II}}$, whereas those at $m / z, 494$ and 585 were attributed to a fragment ion $\left[\left(\eta^{6}-p \text {-cymene }\right) \mathrm{M}^{\mathrm{II}}\left\{\mathbf{L}^{2}-\mathrm{HN}\left(\mathrm{CH}_{3}\right)_{2}\right\}\right]^{+}$, where $\mathrm{M}^{\mathrm{II}}$ is $\mathrm{Ru}^{\mathrm{II}}$ and $\mathrm{Os}^{\mathrm{II}}$. The same type of fragment ions, namely, $\left[\left(\eta^{6}-p \text {-cymene }\right) \mathrm{M}^{\mathrm{II}}\left\{\mathbf{L}^{\mathbf{4}}-\mathrm{HN}\left(\mathrm{CH}_{3}\right)_{2}\right\}\right]^{+}$, were also observed for 9 and 11, but they were clearly less abundant. Peaks at $m / z 561,589,651$, and 679 in the mass spectra of 8-11 were assigned to $\left[\left(\eta^{6}-p \text {-cymene }\right) \mathrm{M}^{\mathrm{II}}\left(\mathbf{L}^{3}\right) \mathrm{Cl}\right]^{+}$and $\left[\left(\eta^{6}-\right.\right.$ $p$-cymene $\left.) \mathrm{M}^{\mathrm{II}}\left(\mathbf{L}^{\mathbf{4}}\right) \mathrm{Cl}\right]^{+}\left(\mathrm{M}^{\mathrm{II}}\right.$ is $\left.\mathrm{Ru}^{\mathrm{II}}, \mathrm{Os}^{\mathrm{II}}\right)$, whereas those at $m / z, 525$ and 613 and at $m / z 553$ and 641 were assigned to $\left[\left(\eta^{6}-p \text {-cymene }\right) \mathrm{M}^{\mathrm{II}}\left(\mathbf{L}^{\mathbf{3}}\right)-\mathrm{HCl}\right]^{+}$and $\left[\left(\eta^{6}-p\right.\right.$-cymene $)$ $\left.\mathrm{M}^{\mathrm{II}}\left(\mathbf{L}^{\mathbf{4}}\right)-\mathrm{HCl}\right]^{+}\left(\mathrm{M}^{\mathrm{II}}\right.$ is $\left.\mathrm{Ru}^{\mathrm{II}}, \mathrm{Os}^{\mathrm{II}}\right)$, respectively.

Both the organic compounds and the metal complexes are soluble in DMSO. By complexation, solubility is significantly altered. Whereas the solubility of the ligands in DMSO is about 2.6 times $\left(\mathbf{L}^{\mathbf{1}}, 360 \mathrm{mM} ; \mathbf{L}^{\mathbf{2}}, 945 \mathrm{mM}\right)$ to 4.5 times $\left(\mathbf{L}^{\mathbf{3}}, 197 \mathrm{mM} ; \mathbf{L}^{\mathbf{4}}, 885 \mathrm{mM}\right)$ higher for the dimethylated species, this ratio is reversed for the complexes. This effect is quite strong in the case of the indoloquinolines, where the solubility of the dimethylated complexes is about one tenth that of the ethane-1,2-diamine species (4, $227 \mathrm{mM}$; 5, $21 \mathrm{mM}$; 6, $235 \mathrm{mM}$; $23 \mathrm{mM}$ ), but is less pronounced for the indolo[3,2- $d]$ benzazepine derivatives by factors of $1.3(\mathbf{8}, 245 \mathrm{mM} ; \mathbf{9}$, $189 \mathrm{mM})$ to $1.4(\mathbf{1 0}, 235 \mathrm{mM} ; \mathbf{1 1}, 167 \mathrm{mM})$. Whereas solubility is about the same for the indoloquinoline- and indolobenzazepine-based ethylenediamine complexes, there are large differences in the case of the dimethylated species, which differ by factors of 9.0 (9 vs. 5) and 7.3 (11 vs. 7), respectively. The difference in solubility between osmium and ruthenium compounds is negligible. The solubility in $1 \%$ DMSO/PBS was also evaluated. The solubility of $\mathbf{4}$ could not be determined, as ligand exchange was so fast that a white precipitate was formed nearly instantaneously after dilution of the DMSO stock solution with PBS. The other indoloquinoline-based complexes (5-7) are more stable and show quite similar solubility: $210 \mu \mathrm{M}(5)$ and $260 \mu \mathrm{M}(6)$. The difference between the comparable ruthenium and osmium compounds (5 and 7) is also negligible. For the indolobenzazepine compounds the situation is different. Whereas the solubility of ruthenium species $\mathbf{8}$ is markedly higher than that of its osmium congener $\mathbf{1 0}$
(315 vs. $110 \mu \mathrm{M}$ ), dimethylated ruthenium and osmium complexes $\mathbf{9}$ and $\mathbf{1 1}$ exhibit the same solubility of about $460 \mu \mathrm{M}$. Notably, this is the highest solubility of all the complexes studied. Dimethylated indolobenzazepine species 9 and 11 exhibit solubility twice as high as the comparable indoloquinoline complexes 5 and 7, where the solubility in $1 \%$ DMSO/PBS is limited by the fairly low solubility in DMSO. Compared with the corresponding ligands, the indoloquinoline-based complexes are slightly less soluble, whereas the indolobenzazepine-based complexes show higher solubility.

The NMR spectra of the racemic complexes show the typical pattern of a molecule with diastereotopic splitting of protons neighboring the chiral metal center. Therefore, four distinct signals for the $p$-cymene protons and two signals for each $\mathrm{CH}_{2}$ group of the ethanediamine moiety can be found. The relative position of the cymene protons cy $1 /$ cy $2 /$ cy 4 and cy $1^{\prime} /$ cy $2^{\prime} /$ cy $4^{\prime}$ was assigned using the twodimensional spectra; the position relative to ligands $\mathbf{L}^{\mathbf{1}}-\mathbf{L}^{\mathbf{4}}$ could not be elucidated.

In the case of 4 , recording of a ${ }^{13} \mathrm{C}$ NMR spectrum and assignment of the resonances was not possible owing to its instability both in DMSO and in methanol. After $24 \mathrm{~h}$ in DMSO- $d_{6}$ complex 4 displayed an NMR spectrum identical with that of the metal-free ligand.

The thermal properties of all complexes were studied by TGA between 25 and $700{ }^{\circ} \mathrm{C}$ under a nitrogen atmosphere (Fig. S4). The TGA curves of 5, 7, and $\mathbf{8}$ indicate that they are nonsolvated. Complexes 4, 6, and 9-11 are solvated species. Desolvation occurs in two consecutive steps $(\mathbf{4}, \mathbf{6}$, and $\mathbf{9}$ ) or in a single step (10 and 11) between 35 and $180{ }^{\circ} \mathrm{C}$ and is accompanied by endothermic peaks in the corresponding DTA curves scanned simultaneously. Endothermic peaks at approximately $220{ }^{\circ} \mathrm{C}$ for $\mathbf{6}$ and $\mathbf{1 1}$ are presumably due to melting, which is followed by decomposition. The thermally most stable is $\mathbf{1 0}$, with decomposition starting at approximately $250{ }^{\circ} \mathrm{C}$. All other compounds have starting decomposition temperatures between 200 and $230{ }^{\circ} \mathrm{C}$, indicating that the thermal stability of both ruthenium(II) and osmium(II) complexes with both indolo[3,2$c]$ quinolines and indolo[3,2- $d$ ]benzazepines is quite similar.

The UV-vis spectra of the methanolic solutions of the ligands are depicted in Fig. S1. Whereas indolo[3,2d] benzazepine derivatives $\mathbf{L}^{\mathbf{3}}$ and $\mathbf{L}^{\mathbf{4}}$ show the strongest absorption at about $230 \mathrm{~nm}$, the indolo[3,2-c] quinolines $\mathbf{L}^{\mathbf{1}}$ and $\mathbf{L}^{\mathbf{2}}$ exhibit a bathochromic shift with absorption maxima at approximately $265 \mathrm{~nm}$. These differences can be explained by the conjugated systems of the indoloquinoline derivatives. The stability of the complexes in methanol (Fig. S2) and 0.5\% DMSO/PBS (Fig. S3) was monitored by UV-vis spectroscopy. In both media indolobenzazepine-based complexes $\mathbf{8 - 1 1}$ are kinetically more inert toward ligand exchange reactions than the metal-based 
indolo[3,2-c]quinolines. In methanol, the UV-vis as well as the ESI mass spectra remained unchanged for $24 \mathrm{~h}$, and in aqueous media only a slight decrease in absorption was observed. The indoloquinoline-based complexes seem to undergo ligand exchange reactions, both in methanol and in aqueous media. The ESI mass spectra of indoloquinoline complexes 4-7 in methanol were measured immediately after dissolution (vide supra) and after $24 \mathrm{~h}$. For $\mathbf{4}$ and $\mathbf{5}$ a new peak with $m / z, 565$ was observed after $24 \mathrm{~h}$, which was attributed to the dimer $\left[\left\{\left(\eta^{6}-p \text {-cymene }\right) \mathrm{Ru}\right\}_{2}\left(\mu-\mathrm{OCH}_{3}\right)_{3}\right]^{+}$. Similarly, the presence of a peak with $m / z, 743$ in the mass spectrum of $\mathbf{7}$ was assigned to $\left[\left\{\left(\eta^{6}-p \text {-cymene }\right) O s\right\}_{2}(\mu-\right.$ $\left.\left.\mathrm{OCH}_{3}\right)_{3}\right]^{+}$. It should be noted that the experimental isotopic patterns agreed well with those calculated. In addition peaks with $\mathrm{m} / z 206$ and 305 indicate the presence of the metal-free ligands in methanolic solutions after $24 \mathrm{~h}$ in the case of 5 and 7. Complex 6 remained intact in methanol over $24 \mathrm{~h}$, revealing a peak with $\mathrm{m} / \mathrm{z}, 601$ attributed to $\left[\left(\eta^{6}-p \text {-cymene }\right) \mathrm{Os}^{\mathrm{II}}\left(\mathbf{L}^{\mathbf{1}}\right)-\mathrm{HCl}\right]^{+}$.

\section{Crystal structures}

The results of the X-ray diffraction studies of the metalfree indolo[3,2-c]quinoline $\mathbf{L}^{\mathbf{1}}$ as a hydrochloride salt, [( $\eta^{6}$ $p$-cymene $\left.) \mathrm{Ru}\left(\mathbf{L}^{\mathbf{1}}\right) \mathrm{Cl}\right] \mathrm{Cl} \cdot \mathrm{H}_{2} \mathrm{O} \quad\left(\mathbf{4} \cdot \mathrm{H}_{2} \mathrm{O}\right), \quad\left[\left(\eta^{6}-p\right.\right.$-cymene $) \mathrm{Ru}$ $\left.\left(\mathbf{L}^{2}\right) \mathrm{Cl}\right] \mathrm{Cl}(\mathbf{5})$, and $\left[\left(\eta^{6}-p\right.\right.$-cymene $\left.) \mathrm{Ru}\left(\mathbf{L}^{4}\right) \mathrm{Cl}\right] \mathrm{Cl} \cdot 2.5 \mathrm{H}_{2} \mathrm{O}(\mathbf{9})$ are shown in Figs. 1, 2, 3, and 4, respectively.

The hydrochloride salt of $\mathbf{L}^{\mathbf{1}}$ crystallized in the orthorhombic space group Pnma. The indolo[3,2-c]quinoline is protonated at the terminal nitrogen atom of the ethylenediamine moiety, as evidenced by hydrogen-bonding interactions between the disordered nitrogen atoms and the chloride counterion. The donor-acceptor separation is $2.917 \AA$ for both disordered nitrogen atoms $\mathrm{N} 4 \cdots \mathrm{Cl}$ and $\mathrm{N} 4 x \cdots \mathrm{Cl}^{\mathrm{i}}(x, y+1, z)$. The indolo[3,2-c]quinoline skeleton lies on a crystallographic mirror plane and is therefore

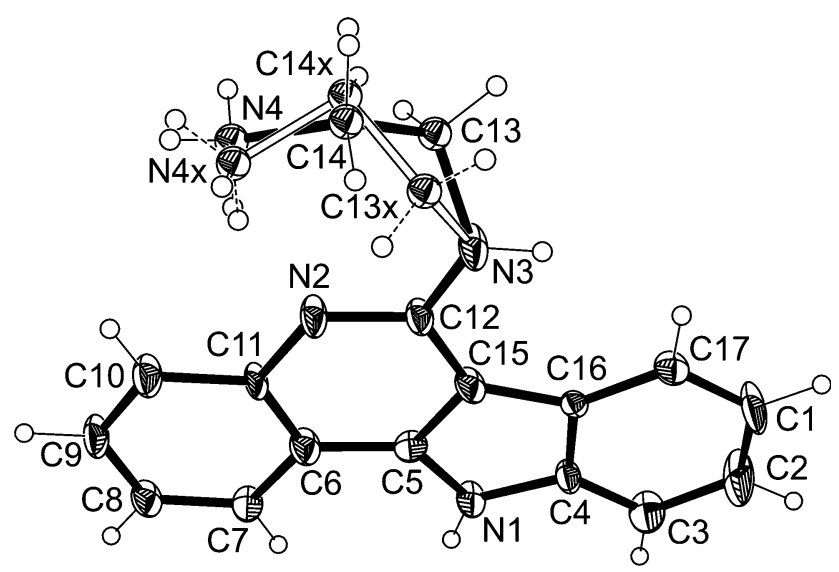

Fig. 1 Structure of the protonated ligand in $\mathbf{L}^{\mathbf{1}} \cdot \mathrm{HCl}$, showing the disorder in the ethylenediamine moiety

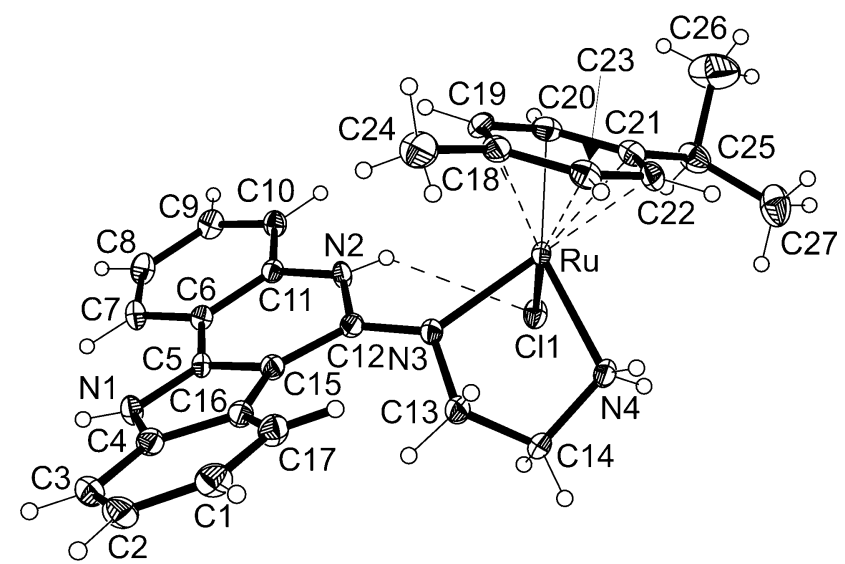

Fig. 2 Structure of the complex cation in $4 \cdot \mathrm{H}_{2} \mathrm{O}$ with thermal ellipsoids drawn at the $50 \%$ probability level

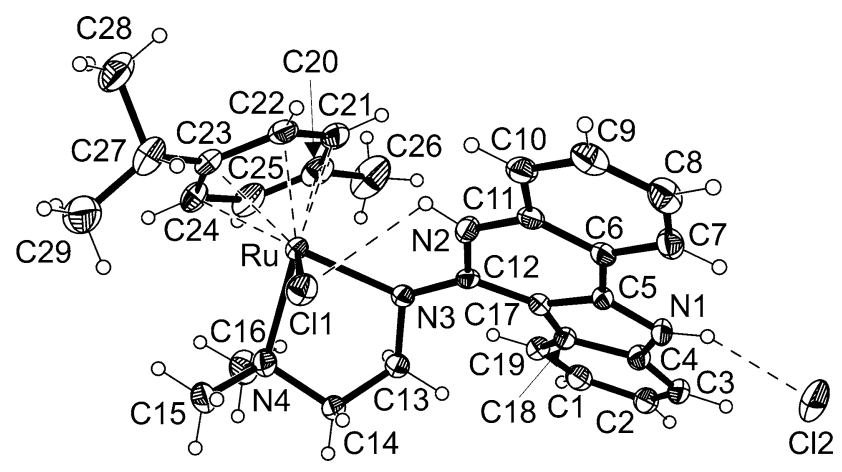

Fig. 3 Fragment of the crystal structure of $\mathbf{5}$ with thermal ellipsoids drawn at the $30 \%$ probability level with one intramolecular hydrogen bond $\mathrm{N} 2-\mathrm{H} \cdots \mathrm{Cl} 1$ and one intermolecular hydrogen bond $\mathrm{N} 1-\mathrm{H} \cdots \mathrm{Cl} 2^{\mathrm{i}}$

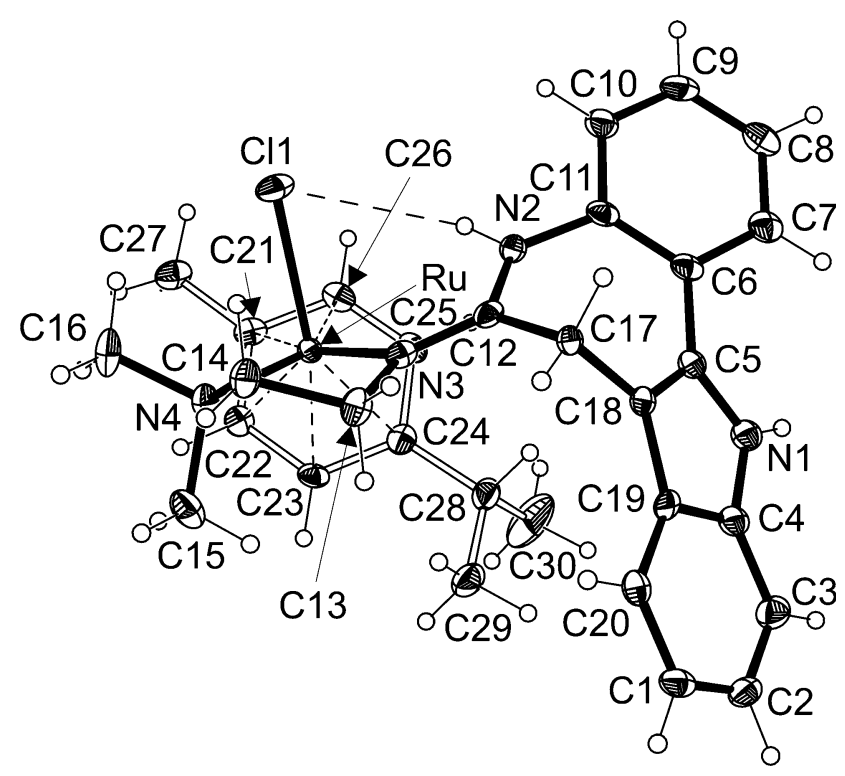

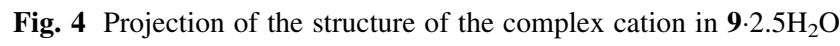
with thermal ellipsoids drawn at the $50 \%$ probability level with an intramolecular hydrogen-bonding interaction $\mathrm{N} 2-\mathrm{H} \cdots \mathrm{Cl} 1$ 
perfectly planar. The distribution of the electron density over the fragment N2-C12-N3 [N2-C12 1.339(9) ̊̊, C12$\mathrm{N} 31.352(8) \AA]$ indicates the prevalence of the tautomeric form with the endocyclic amidine $\mathrm{C}=\mathrm{N}$ bond.

All complexes have the characteristic "three-leg pianostool" geometry of ruthenium(II) arene complexes [28, 4649], with an $\eta^{6} \pi$-bound $p$-cymene ring forming the seat and three other donor atoms (of one bidentate indolo[3,2$c$ ]quinoline or indolo[3,2- $d$ ] benzazepine ligand and one chlorido ligand) as the legs of the stool. Selected bond distances and angles are given in Table 2. The complexes are racemates owing to the presence of the stereogenic metal center. Complexes $\mathbf{4} \cdot \mathrm{H}_{2} \mathrm{O}$ and $\mathbf{5}$ are the first metalbased indolo[3,2-c]quinolines characterized crystallographically. The indolo[3,2-c]quinoline ligands in $\mathbf{4}$ and $\mathbf{5}$ adopt tautomeric forms different from that found in the metal-free compound $\mathbf{L}^{\mathbf{1}} \cdot \mathrm{HCl}$, with an exocyclic amidine double bond, as can be clearly seen from the distribution of the electron density over the fragments N2-C12-N3 [N2-C12 1.379(2) and 1.377(5) $\AA, \mathrm{C} 12-\mathrm{N} 3$ 1.315(2) and 1.331(5) $\AA$, for $\mathbf{4} \cdot \mathrm{H}_{2} \mathrm{O}$ and 5, respectively]. Upon binding to ruthenium(II), the ligands form a five-membered metallocycle N3C13C14N4Ru. The torsion angle $\Theta_{\mathrm{N} 3-\mathrm{C} 13-\mathrm{C} 14-\mathrm{N} 4}$, which serves as a measure of the deviation of the chelate ring from planarity, is $56.12(19)^{\circ}$ and $58.7(4)^{\circ}$ in $4 \cdot \mathrm{H}_{2} \mathrm{O}$ and $\mathbf{5}$, respectively.

A hydrogen bond between indole nitrogen $\mathrm{N} 1$ as a proton donor and the chloride counterion $\mathrm{Cl}_{2}{ }^{\mathrm{i}}$ (symmetry code $\mathrm{i}$ : $-x+1 / 2, y+1 / 2,-z+1 / 2$ ) as a proton acceptor (Fig. 3 ) is also evident in the crystal structure of 5 [N1-H $0.86 \AA$, $\mathrm{H} \cdots \mathrm{Cl} 2^{\mathrm{i}} 2.270 \AA, \mathrm{N} 1 \cdots \mathrm{Cl} 23.075 \AA$, N1HCl2 ${ }^{\mathrm{i}} 155.94^{\circ}$ ].

A salient feature in the structure of $9 \cdot 2.5 \mathrm{H}_{2} \mathrm{O}$ is the folded conformation of the indolobenzazepine ligand $\mathbf{L}^{\mathbf{4}}$ bound to ruthenium. In contrast to the essentially planar indolo[3,2-c]quinoline backbone (see Fig. 1), the indolo$[3,2-d]$ benzazepine main skeleton contains one $s p^{3}-$ hybridized carbon atom, i.e., the methylene group of the seven-membered azepine ring. This atom interrupts the conjugation of the $\pi$ system, and the ligand as a whole is nonplanar. The dihedral angle between the phenyl and indole rings can be characterized by a torsion angle of $\Theta_{\mathrm{N} 1-\mathrm{C} 5-\mathrm{C} 6-\mathrm{C} 7}$, which is $-33.5(6)^{\circ}$ compared with $-36.84(18)^{\circ}$ in the metal-free 9-bromo-indolo[3,2- $\left.d\right]$ benzazepine [50]. $\mathbf{L}^{\mathbf{3}}$ and $\mathbf{L}^{\mathbf{4}}$ act as neutral ligands and are stabilized in a different tautomeric form compared with that in the metal-free derivative brominated at position 9 . The hydrogen atom is attached to N2, and the N2-C12 bond length of 1.357(6) $\AA$ is significantly longer than $\mathrm{C} 12$ $\mathrm{N} 3$ of $1.302(5) \AA$, the latter possessing a pronounced double-bond character. Intramolecular hydrogen bonding between $\mathrm{N} 2$ and $\mathrm{Cl} 1[\mathrm{~N} 2-\mathrm{H} \quad 0.880, \mathrm{H} \cdots \mathrm{Cl} 12.722 \AA$,

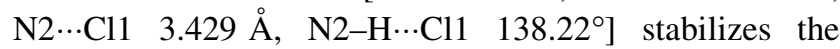
ligand in $E$ configuration with the exocyclic double $\mathrm{C}=\mathrm{N}$ bond. Upon binding to ruthenium(II), the ligand forms a five-membered N3C13C14N4Ru metallocycle. The torsion angle $\Theta_{\mathrm{N} 3-\mathrm{C} 13-\mathrm{C} 14-\mathrm{N} 4}$ is $54.9(5)^{\circ}$ in $\mathbf{9} \cdot 2.5 \mathrm{H}_{2} \mathrm{O}$.

\section{Cytotoxicity in cancer cell lines}

The cytotoxicity of compounds $\mathbf{L}^{2}, \mathbf{L}^{\mathbf{4}}$, and $\mathbf{5}-\mathbf{1 1}$ was assessed by means of a colorimetric microculture assay (MTT assay) in three human cancer cell lines, namely, CH1 (ovarian carcinoma), SW480 (colon adenocarcinoma), and A549 (non-small-cell lung carcinoma). The sensitivities of these cell lines show mostly small differences, but the generally more chemoresistant non-small-cell lung cancer cell line A549 is also the least sensitive throughout this series of compounds. The generally more chemosensitive ovarian cancer cell line $\mathrm{CH} 1$ is the most sensitive only to indolobenzazepine derivatives $\mathbf{L}^{\mathbf{4}}$ and $\mathbf{8}-\mathbf{1 1}$, whereas indoloquinoline derivatives $\mathbf{L}^{\mathbf{2}}$ and $\mathbf{5 - 7}$ are most cytotoxic to the colon cancer cell line SW480. The calculated $\mathrm{IC}_{50}$ values are listed in Table 3 , and the corresponding concentration-effect curves are depicted in Figs. 5, 6, and 7, illustrating the following structure-activity relationships: the high cytotoxic potency of indoloquinoline derivative $\mathbf{L}^{2}$ could only be slightly (if at all) increased by complexation, with hardly a difference between ruthenium and osmium (up to 1.8 times in the case of ruthenium complex $\mathbf{5}$ and up to 1.6 times in the case of osmium complex 7 , based on a

Table 2 Selected bond distances (angstroms) and angles (degrees) for complexes $\mathbf{4} \cdot \mathrm{H}_{2} \mathrm{O}$, 5, and $\mathbf{9} \cdot 2.5 \mathrm{H}_{2} \mathrm{O}$

\begin{tabular}{llll}
\hline & $\mathbf{4} \cdot \mathrm{H}_{2} \mathrm{O}$ & $\mathbf{5}$ & $\mathbf{9} \cdot 2.5 \mathrm{H}_{2} \mathrm{O}$ \\
\hline $\mathrm{Ru}-\mathrm{N} 3$ & $2.1174(15)$ & $2.105(3)$ & $2.122(3)$ \\
$\mathrm{Ru}-\mathrm{N} 4$ & $2.1257(15)$ & $2.204(3)$ & $2.177(3)$ \\
$\mathrm{Ru}-\mathrm{Cl} 1$ & $2.4208(5)$ & $2.4229(11)$ & $2.4168(11)$ \\
$\mathrm{Ru}-\mathrm{C}(18-23) \mathrm{av} / \mathrm{Ru}-\mathrm{C}(20-25) \mathrm{av} / \mathrm{Ru}-\mathrm{C}(21-26) \mathrm{av}$ & $2.186(14)$ & $2.191(24)$ & $2.197(8)$ \\
$\mathrm{C}-\mathrm{C}(18-23) \mathrm{av} / \mathrm{C}-\mathrm{C}(20-25) \mathrm{av} / \mathrm{C}-\mathrm{C}(21-26) \mathrm{av}$ & $1.416(14)$ & $1.404(20)$ & $1.412(17)$ \\
$\mathrm{N} 3-\mathrm{Ru}-\mathrm{N} 4$ & $79.26(6)$ & $80.45(12)$ & $79.44(14)$ \\
$\mathrm{N} 3-\mathrm{Ru}-\mathrm{Cl1}$ & $88.79(4)$ & $87.15(9)$ & $85.01(10)$ \\
$\mathrm{N} 4-\mathrm{Ru}-\mathrm{Cl1}$ & $85.12(4)$ & $88.27(10)$ & $88.41(10)$ \\
\hline
\end{tabular}


Table 3 Cytotoxicity of indoloquinoline and indolobenzazepine derivatives, their osmium(II) and ruthenium(II) arene complexes, and flavopiridol in three human cancer cell lines

\begin{tabular}{lccc}
\hline Compound & $\mathrm{IC}_{50}(\mu \mathrm{M})^{\mathrm{a}}$ & & \\
\cline { 2 - 4 } & $\mathrm{CH} 1$ & $\mathrm{SW} 480$ & $\mathrm{~A} 549$ \\
\hline $\mathbf{L}^{\mathbf{2}}$ & $0.51 \pm 0.05$ & $0.28 \pm 0.01$ & $0.92 \pm 0.18$ \\
$\mathbf{5}$ & $0.44 \pm 0.03$ & $0.23 \pm 0.01$ & $0.50 \pm 0.05$ \\
$\mathbf{6}$ & $0.39 \pm 0.04$ & $0.22 \pm 0.03$ & $0.82 \pm 0.06$ \\
$\mathbf{7}$ & $0.44 \pm 0.07$ & $0.27 \pm 0.003$ & $0.58 \pm 0.10$ \\
$\mathbf{L}$ & $21 \pm 3$ & $25 \pm 1$ & $44 \pm 1$ \\
$\mathbf{8}$ & $4.3 \pm 0.4$ & $5.7 \pm 0.3$ & $9.7 \pm 1.6$ \\
$\mathbf{9}$ & $1.3 \pm 0.1$ & $2.8 \pm 0.2$ & $6.5 \pm 1.0$ \\
$\mathbf{1 0}$ & $3.5 \pm 0.1$ & $5.8 \pm 0.2$ & $13 \pm 0.5$ \\
$\mathbf{1 1}$ & $2.0 \pm 0.6$ & $3.6 \pm 0.3$ & $8.8 \pm 0.3$ \\
Flavopiridol & $0.029 \pm 0.005$ & $0.070 \pm 0.004$ & $0.13 \pm 0.01$ \\
\hline
\end{tabular}

${ }^{a}$ The $50 \%$ inhibitory concentrations (mean \pm standard deviations from at least three independent experiments), as obtained by the MTT assay (continuous exposure for $96 \mathrm{~h}$ )

comparison of $\mathrm{IC}_{50}$ values), which might result from insufficient stability in the cell culture medium. In any case, there are no clear-cut synergistic effects of metal and ligand. The cytotoxicity of complex $\mathbf{6}$ differs only slightly from that of analogue 7, showing that terminal dimethylation of the ethane-1,2-diamine side chain has little consequence for biological activity (Fig. 5).

In contrast, the cytotoxic potency of indolobenzazepine derivative $\mathbf{L}^{\mathbf{4}}$ could be markedly enhanced by complexation, but again with little difference between ruthenium and osmium. This enhancement amounts to 6.8-16-fold, depending on the cell line, in the case of ruthenium complex $\mathbf{9}$ and fivefold to tenfold in the case of osmium complex $\mathbf{1 1}$. The terminally dimethylated ethane-1,2-diamine side chain is slightly favorable in terms of cytotoxicity, as reflected by the 1.5-3.3 and 1.5-1.8 times higher $\mathrm{IC}_{50}$ values of $\mathbf{8}$ and $\mathbf{1 0}$ in comparison with $\mathbf{9}$ and 11, respectively (Table 3, Fig. 6).

A comparison of the indolo[3,2-c]quinoline derivatives with the indolo[3,2- $d]$ benzazepine derivatives reveals that the $\mathrm{IC}_{50}$ values of the former are all in the high nanomolar range, whereas those of the latter are mostly in the low micromolar range. The cytotoxicities of uncomplexed derivatives $\mathbf{L}^{\mathbf{2}}$ and $\mathbf{L}^{\mathbf{4}}$ differ by factors of 41-89, depending on the cell line. The differences are smaller but still pronounced in the case of the ruthenium complexes (factors of 3-13 for the couple 5/9) and the osmium complexes (factors of 9-26 and 4.5-15 for the couples $\mathbf{6 / 1 0}$ and $\mathbf{7 / 1 1}$, respectively) (Fig. 7).

DNA intercalation

The intercalation of compounds $\mathbf{L}^{2}, \mathbf{L}^{\mathbf{4}}, \mathbf{7}$, and $\mathbf{1 1}$ into DNA was assessed by treating salmon sperm DNA with
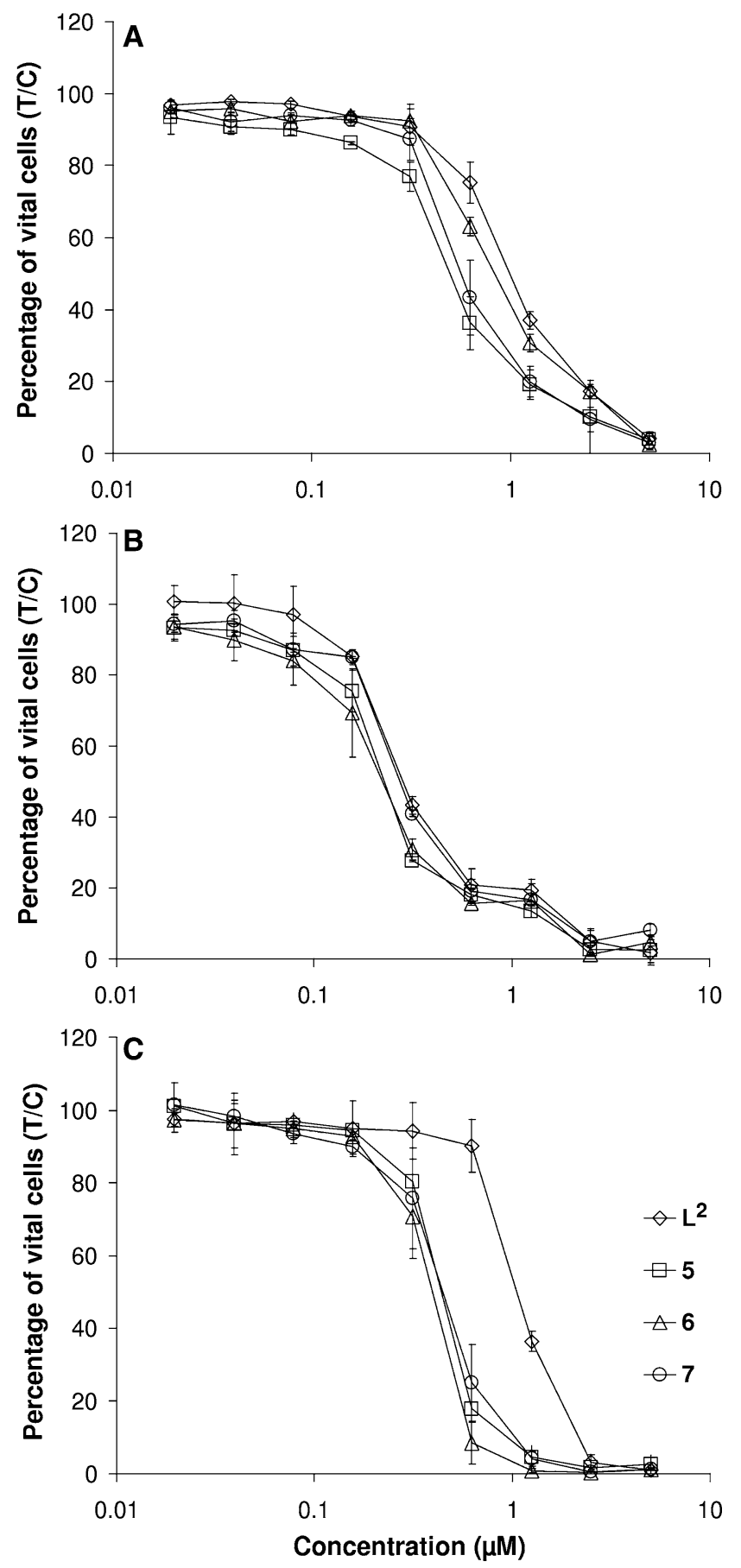

Fig. 5 Concentration-effect curves of indoloquinoline derivative $\mathbf{L}^{2}$ in comparison with ruthenium complex $\mathbf{5}$ and osmium complexes $\mathbf{6}$ and 7 in the human cancer cell lines A549 (a), SW480 (b) and CH1 (c), as obtained by the 3-(4,5-dimethyl-2-thiazolyl)-2,5-diphenyl- $2 \mathrm{H}$ tetrazolium bromide (MTT) assay (continuous exposure for $96 \mathrm{~h}$ )

methyl green and measuring the competitive replacement of methyl green by the compounds after incubation for $2 \mathrm{~h}$ through the decrease of the optical density at $642 \mathrm{~nm}$. Osmium indolo[3,2- $d$ ] benzazepine complex 11 and metalfree indolobenzazepine $\mathbf{L}^{\mathbf{4}}$ show a certain intercalating 

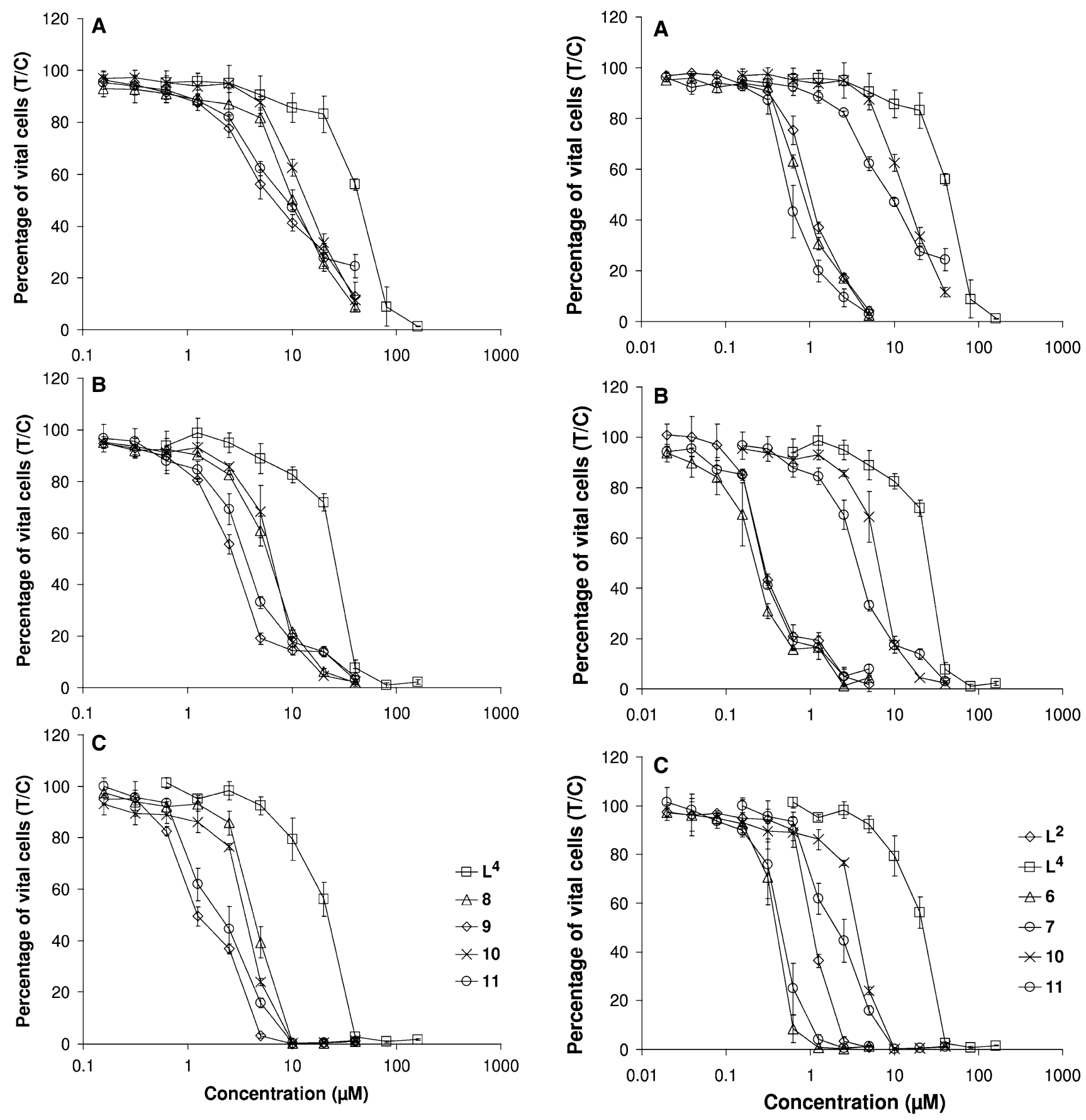

Fig. 6 Concentration-effect curves of indolobenzazepine derivative $\mathbf{L}^{4}$ in comparison with ruthenium complexes $\mathbf{8}$ and $\mathbf{9}$ and osmium complexes $\mathbf{1 0}$ and $\mathbf{1 1}$ in the human cancer cell lines A549 (a), SW480 (b), and $\mathrm{CH} 1$ (c), as obtained by the MTT assay (continuous exposure for $96 \mathrm{~h}$ )

capacity, which hardly exceeds $50 \%$ replacement of methyl green even at the highest concentration tested, however. The indoloquinoline compounds $\mathbf{L}^{2}$ and $\mathbf{7}$ replace methyl green even more efficiently (about 90\%) than the well known intercalating agent ethidium bromide (Fig. 8), adding another molecular effect potentially relevant for

Fig. 7 Concentration-effect curves of osmium complexes $\mathbf{6}, \mathbf{7}, \mathbf{1 0}$, and $\mathbf{1 1}$ in comparison with uncomplexed ligands $\mathbf{L}^{\mathbf{2}}$ and $\mathbf{L}^{\mathbf{4}}$ in the human cancer cell lines A549 (a), SW480 (b), and CH1 (c), as obtained by the MTT assay (continuous exposure for $96 \mathrm{~h}$ )

cytotoxicity. These results are not unexpected, given the planar structure of the indoloquinolines, which should fit better between the nucleotides of DNA than the folded indolobenzazepines, and considering that benzoindolo[3,2$c$ ]quinolines have been previously reported to intercalate into DNA [51]. 


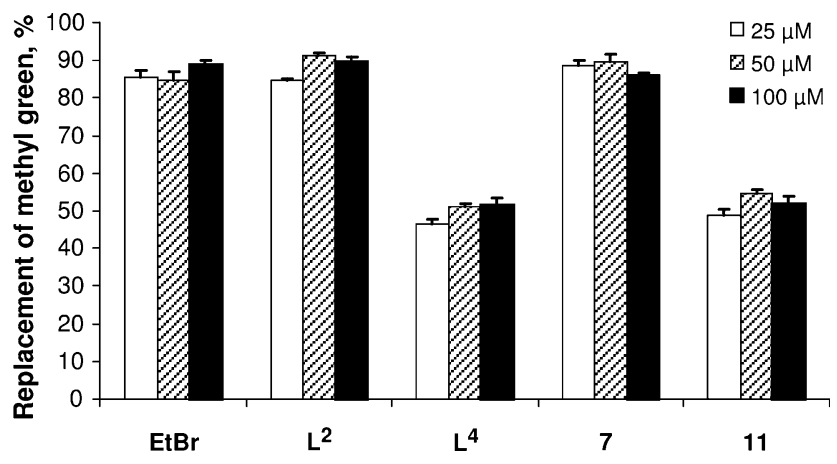

Fig. 8 Replacement of methyl green from salmon sperm DNA as a measure for DNA intercalation, using ethidium bromide $(E t B r)$ as a positive control (mean \pm standard deviations)

\section{Inhibition of cdk activity}

Measurements of kinase activity of recombinant cdk/cyclin complexes after exposure to indoloquinoline $\mathbf{L}^{2}$, indolobenzazepine derivative $\mathbf{L}^{\mathbf{4}}$, and the corresponding osmium complexes $\mathbf{7}$ and $\mathbf{1 1}$ were performed in the presence of $\left(\gamma_{-}{ }^{32} \mathrm{P}\right) \mathrm{ATP}$ and histone H1 as the substrate for phosphorylation. Generally, the activity of cdk $2 /$ cyclin E was affected by the test compounds (including the cdk inhibitor flavopiridol, which was used as a reference) to a higher degree than that of cdk1/cyclin B, except for 11, which inhibits both kinases to nearly equal extent. Whereas the $\mathrm{IC}_{50}$ value for cdk1/cyclin $\mathrm{B}$ inhibition was only reached within the concentration range up to $100 \mu \mathrm{M}$ in the case of $\mathbf{1 1}(90 \mu \mathrm{M})$, those for cdk2/cyclin E inhibition decrease in the following rank order: $11(100 \mu \mathrm{M})>\mathbf{L}^{\mathbf{4}}$ $(73 \mu \mathrm{M})>\mathbf{L}^{\mathbf{2}}(70 \mu \mathrm{M})>\mathbf{7}(13 \mu \mathrm{M})$. Thus, the inhibitory potency of $\mathbf{L}^{2}$ resembles that of $\mathbf{L}^{\mathbf{4}}$, despite the 2 orders of magnitude higher cytotoxicity, strongly suggesting that other molecular effects account for the increased cytotoxicity. Complexation with osmium has different consequences for kinase inhibition. Whereas complex 7 inhibits cdk2/cyclin $\mathrm{E}$ to a somewhat higher degree than uncomplexed indoloquinoline $\mathbf{L}^{\mathbf{2}}$, comparison of complex $\mathbf{1 1}$ with indolobenzazepine derivative $\mathbf{L}^{\mathbf{4}}$ reveals an increased inhibitory activity in cdk1/cyclin B only (Figs. 9, 10).

Thus, all of the four selected compounds are capable of inhibiting cdk activity in vitro. As the inhibitory potencies do not parallel the cytotoxicities, which differ greatly, it is unlikely that cdk2 inhibition is the crucial effect accounting for their cytotoxicity, however. When considering that the concentration required even for inhibition of cdk2/cyclin $\mathrm{E}$ appears rather high, one should keep in mind that in the case of flavopiridol, a prototypic cdk inhibitor, the $\mathrm{IC}_{50}$ value for cdk2/cyclin E inhibition (approximately $0.3 \mu \mathrm{M}$ ) is also higher than those in the MTT assay (0.029$0.13 \mu \mathrm{M})$. This apparent discrepancy may be explained by the facts that flavopiridol inhibits other kinases, such as

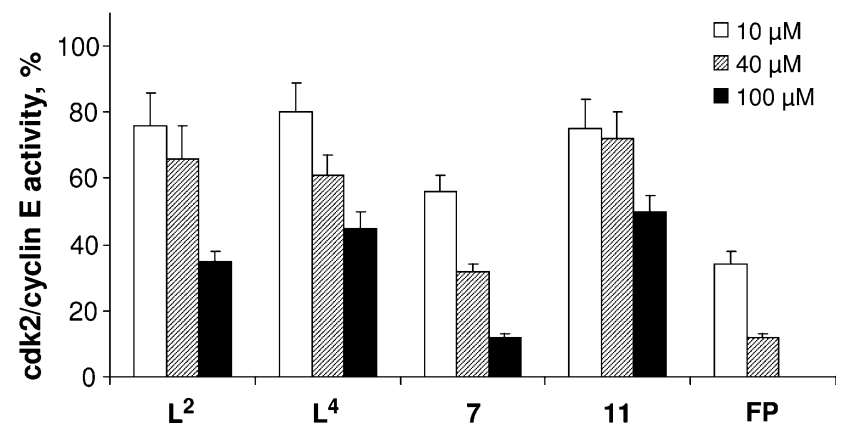

Fig. 9 Concentration-dependent inhibition of cdk2/cyclin E activity (mean \pm standard deviations) by indoloquinoline $\mathbf{L}^{2}$, indolobenzazepine derivative $\mathbf{L}^{\mathbf{4}}$, and the corresponding osmium complexes $\mathbf{7}$ and 11, in vitro. Flavopiridol $(F P)$ was used as a positive control

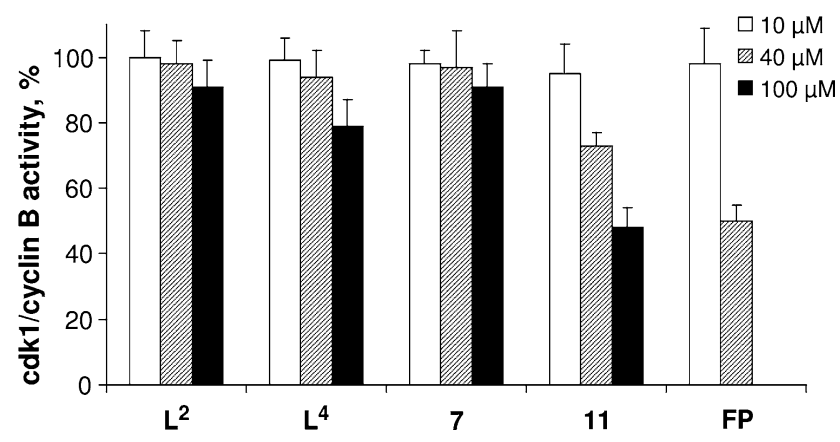

Fig. 10 Concentration-dependent inhibition of cdk1/cyclin B activity (mean \pm standard deviations) by indoloquinoline $\mathbf{L}^{\mathbf{2}}$, indolobenzazepine derivative $\mathbf{L}^{4}$, and the corresponding osmium complexes 7 and 11, in vitro. Flavopiridol $(F P)$ was used as a positive control

cdk4/cyclin D and cdk6/cyclin D [52], cdk7 [53], and cdk9 [54], with much higher potency and that the inhibition of just cdk2 is generally not sufficient for the induction of cell death, as demonstrated by Berthet et al. [55] in cdk2knockout mice.

\section{Cell cycle effects}

To study changes in cell cycle distribution induced by $\mathbf{L}^{2}$, $\mathbf{L}^{\mathbf{4}}, \mathbf{7}$, and 11, exponentially growing A549 cells were treated with these compounds in various concentrations for $24 \mathrm{~h}$, then stained with propidium iodide and analyzed for their DNA content by flow cytometry. These experiments showed that indoloquinoline $\mathbf{L}^{2}$ and the corresponding osmium complex 7 have comparable effects on the cell cycle, which vary strongly depending on the concentration (Fig. 11). Whereas $1 \mu \mathrm{M}$ concentration of these compounds induces a marked G2/M arrest, the S-phase fraction increases to more than double the amount at the expense of both the G0/G1 and G2/M fractions at concentrations of $4 \mu \mathrm{M}$. No S-phase arrest is discernible at concentrations of 

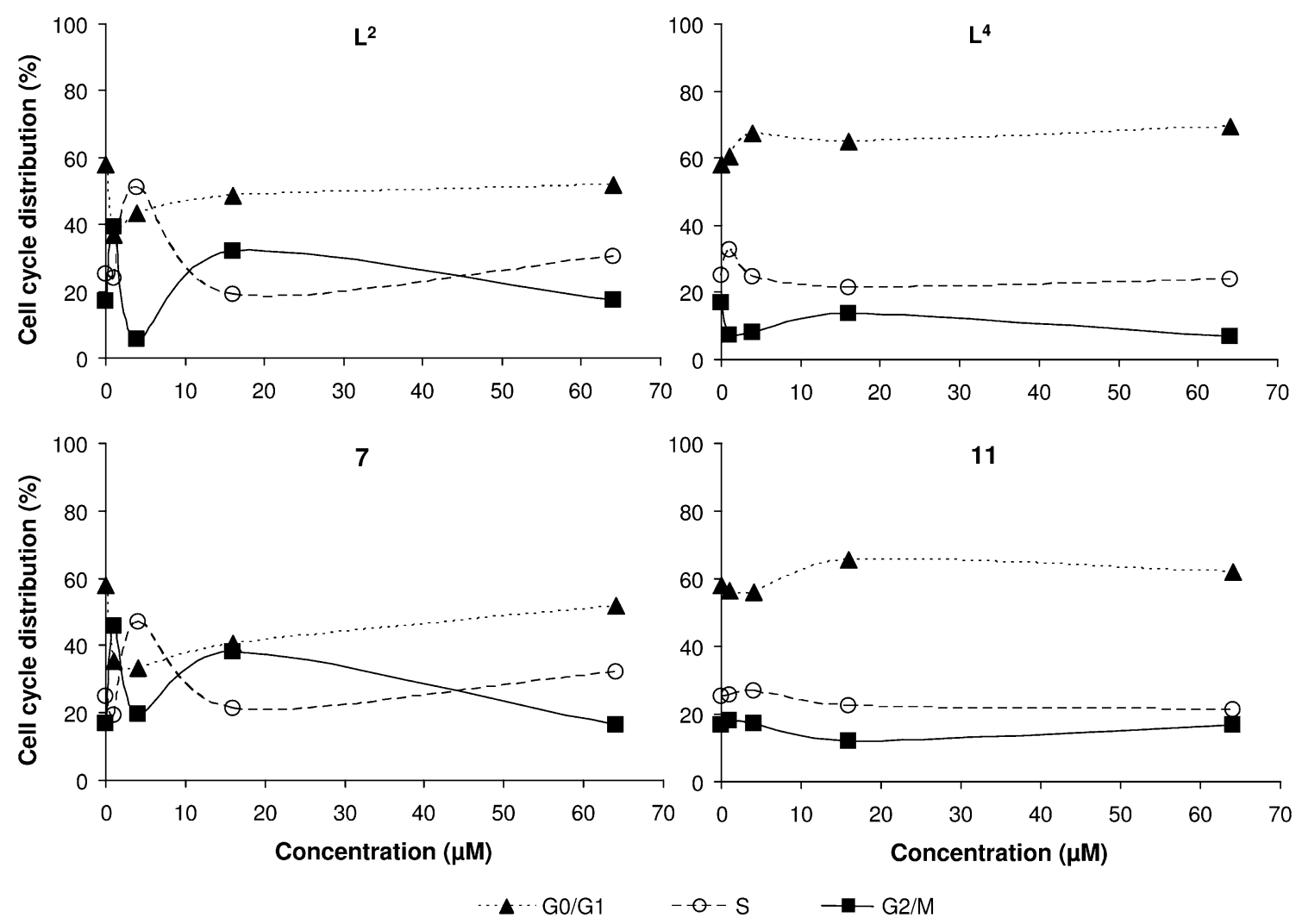

Fig. 11 Concentration-dependent impact of $\mathbf{L}^{\mathbf{2}}, \mathbf{L}^{\mathbf{4}}, \mathbf{7}$, and $\mathbf{1 1}$ on the cell cycle distribution of A549 cells after exposure for 24 h. The DNA content of cells stained with propidium iodide was analyzed by flow cytometry

$16 \mu \mathrm{M}$, which might indicate cell death preferentially in the $\mathrm{S}$ phase. At the highest concentration tested $(64 \mu \mathrm{M})$, the phase distributions converge to that of the control, suggestive of a loss of phase specificity. Thus, the cellular effects of the highly cytotoxic indoloquinolines cause strong cell cycle perturbations, even though the results of the kinase inhibition experiments described earlier do not support cdks as their principal targets. In sharp contrast, indolobenzazepine derivative $\mathbf{L}^{\mathbf{4}}$ and the corresponding osmium complex $\mathbf{1 1}$ exert very minor effects on the cell cycle, despite their similar cdk-inhibitory potencies in the cell-free setting.

\section{Conclusions}

The results presented herein establish synthetic access to a new family of metal-based indolo[3,2-c]quinolines, in addition to a closely related class of metal-based indolo[3,2$d$ ]benzazepines (paullones), extending our previous work on the latter class of compounds. A number of ruthenium(II) arene and osmium(II) arene complexes with indolo[3,2-c]quinolines and indolo[3,2- $d$ ] benzazepines have been prepared, enabling a comparative estimation of the solubility, thermal stability, hydrolytic behavior, and antiproliferative activity of the two closely related classes of organic molecules. The compounds inhibit cancer cell proliferation, and structure-activity relationships have been elucidated. In particular, replacement of the seven-membered nonplanar azepine ring in indolo[3,2- $d]$ benzazepines by a six-membered flat ring in indolo[3,2-c]quinolines resulted in a pronounced enhancement of cytotoxicity. Metal-free indolo[3,2-c] quinolines revealed $\mathrm{IC}_{50}$ values in the high nanomolar range, whereas closely related indolo[3,2- $d]$ benzazepines had $\mathrm{IC}_{50}$ values in the low micromolar range. This might be due to the higher ability of the flat indolo[3,2-c]quinoline backbone to intercalate into DNA, in contrast to the folded molecule structure of the related indolo[3,2- $d]$ benzazepine derivatives. Complexation of indolo[3,2-c]quinolines with ruthenium(II) arene and osmium(II) arene scaffolds results in a slight (if at all) increase of antiproliferative activity, with a very small difference between ruthenium and osmium, whereas binding of indolobenzazepine $\mathbf{L}^{\mathbf{4}}$ to ruthenium(II) and osmium(II) gives rise to a 6.8-16-fold and a fivefold to tenfold enhancement of cytotoxic potency, respectively, depending on the cell line. Different effects of metal coordination for indolo[3,2-c]quinolines and indolo[3,2- $d]$ benzazepines in terms of cytotoxicity might be a result of higher kinetic lability of metal-based indolo[3,2-c]quinolines in cell culture 
medium. Time-dependent UV-vis measurements provided evidence for the increased lability toward ligand-exchange reactions at the metal center of metal-based indolo[3,2-c]quinolines compared with metallated indolo[3,2- $d]$ benzazepines. Terminal dimethylation of the ethane-1,2-diamine side chain has little effect on biological activity of ruthenium and osmium complexes, being slightly more favorable in the case of metal-based indolobenzazepines. Cell cycle perturbations are pronounced in cancer cells treated with the indoloquinolines, but are almost negligible in the case of the paullone derivatives. In cell-free experiments, all compounds studied proved to be capable of inhibition of cdk activity, as exemplified by cdk2/cyclin E. However, a synopsis of structure-activity relationships with regard to cytotoxicity, cell cycle effects and kinase inhibition does not support cdk 1 and cdk 2 as the principal targets of these compounds.

Acknowledgments We thank A. Roller for the collection of X-ray data sets, P. Unfried for measuring the TGA/DTA curves, and M. Galanski for the measurement of NMR spectra. V.B.A. is indebted to H.-G. Schmalz (Institute of Organic Chemistry, University of Cologne) for a stimulating discussion. G. Schmetterer (Institute of Physical Chemistry, University of Vienna) and I. Herbacek (Institute of Cancer Research, Department of Medicine I, Medical University of Vienna) are also gratefully acknowledged for providing the radiochemical facilities for kinase experiments and for flow cytometry analyses, respectively. This work was supported by the FWF (Austrian Science Fund, project numbers P20897 and P22339).

Open Access This article is distributed under the terms of the Creative Commons Attribution Noncommercial License which permits any noncommercial use, distribution, and reproduction in any medium, provided the original author(s) and source are credited.

\section{References}

1. Tominaga $\mathrm{M}$, Tone $\mathrm{H}$, Nakagawa $\mathrm{K}$, Takada $\mathrm{K}$, Hoshino $\mathrm{Y}$, Watanabe K (1981) Chem Pharm Bull 29:2166-2181

2. Nishi T, Yamamoto K, Shimizu T, Kanbe T, Kimura Y, Nakagawa K (1983) Chem Pharm Bull 31:798-810

3. Nishi T, Tabusa F, Tanaka T, Shimizu T, Kanbe T, Kimura Y, Nakagawa K (1983) Chem Pharm Bull 31:1151-1157

4. Alabaster CT, Bell AS, Campbell SF, Ellis P, Henderson CG, Roberts DA, Ruddock KS, Samuels GMR, Stefaniak MH (1988) J Med Chem 31:2048-2056. doi:10.1021/jm00118a034

5. Alabaster CT, Bell AS, Campbell SF, Ellis P, Henderson CG, Morris DS, Roberts DA, Ruddock KS, Samuels GMR, Stefaniak MH (1989) J Med Chem 32:575-583. doi:10.1021/jm00123a011

6. Fujioka T, Teramoto S, Mori T, Hosokawa T, Sumida T, Tominaga M, Yabuuchi Y (1992) J Med Chem 35:3607-3612. doi: 10.1021/jm00098a003

7. Lipworth BJ, Grove A (1997) Br J Clin Pharmacol 43:9-14. doi: 10.1111/j.1365-2125.1997.tb00130.x

8. Tzeng CC, Lee KH, Wang TC, Han CH, Chen YL (2000) Pharm Res 17:715-719. doi:10.1023/A:1007534416561
9. Rowinsky EK, Donehower RC (1998) In: Perry MC (ed) The chemotherapy source book, vol 2. Williams \& Wilkins, Baltimore, p 387

10. Donehower RC, Rowinsky EK (1993) In: De Vita VT, Hellman S, Rosenberg SA (eds) Cancer: principles and practice of oncology. Lippincott, Philadelphia, p 409

11. Molina P, Alajarin M, Vidal A (1990) Tetrahedron 46:10631078. doi:10.1016/S0040-4020(01)81384-3

12. Stadlbauer W (1986) Monatsh Chem 117:1305-1323. doi: 10.1007/BF00810876

13. Stadlbauer W, Karem A-S, Kappe T (1987) Monatsh Chem 118:81-89. doi:10.1007/BF00810043

14. MacPhillamy HB, Dziemian RL, Lucas RA, Kuehne ME (1958) J Am Chem Soc 80:2172-2178. doi:10.1021/ja01542a035

15. Bergman J, Engqwist R, Stalhandske C, Wallberg H (2003) Tetrahedron 59:1033-1048. doi:10.1016/S0040-4020(02)01647-2

16. Chen Y-L, Chung C-H, Chen I-L, Chen P-H, Jeng H-Y (2002) Bioorg Med Chem 10:2705-2712. doi:10.1016/S0968-0896(02) 00111-6

17. Lamazzi C, Léonce S, Pfeiffer B, Renard P, Guillaumet G, Rees CW, Besson T (2000) Bioorg Med Chem Lett 10:2183-2185. doi: 10.1016/S0960-894X(00)00427-3

18. Zaharewitz DW, Gussio R, Leost M, Senderowitz AM, Lahusen T, Kunick C, Meijer L, Sausville EA (1999) Cancer Res 59:2566-2569

19. Dobrov A, Arion VB, Kandler N, Ginzinger W, Jakupec MA, Rufinska A, Graf von Keyserlingk N, Galanski M, Kowol C, Keppler BK (2006) Inorg Chem 45:1945-1950. doi:10.1021/ic0511120

20. Schmid WF, Zorbas-Seifried S, John RO, Arion VB, Jakupec MA, Roller A, Galanski M, Chiorescu I, Zorbas H, Keppler BK (2007) Inorg Chem 46:3645-3656. doi:10.1021/ic070098j

21. Schmid WF, John RO, Mühlgassner G, Heffeter P, Jakupec MA, Galanski M, Berger W, Arion VB, Keppler BK (2007) J Med Chem 50:6343-6355. doi:10.1021/jm701042w

22. Schmid WF, John RO, Arion VB, Jakupec MA, Keppler BK (2007) Organometallics 26:6643-6652. doi:10.1021/om700813c

23. Ginzinger W, Arion VB, Giester G, Galanski M, Keppler BK (2008) Cent Eur J Chem 6:340-346. doi:10.2478/s11532-0080048-X

24. Becker A, Kohfeld S, Pies T, Wieking K, Preu L, Kunick C (2009) Synthesis 1185-1189. doi:10.1055/s-0028-1088014

25. Hu X-W, Chien C-M, Yang S-H, Lin Y-H, Lu C-M, Chen Y-L, Lin S-R (2006) Cell Biol Toxicol 22:417-427. doi: 10.1007/s10565-006-0098-9

26. Yang S-H, Chien C-M, Lu C-M, Chen Y-L, Chang L-S, Lin S-R (2007) Leuk Res 31:1413-1420. doi:10.1016/j.leukres.2007.02. 014

27. Chien C-M, Yang S-H, Lin K-L, Chen Y-L, Chang L-S, Lin S-R (2008) Chem Biol Interact 176:40-47. doi:10.1016/j.cbi.2008. 06.008

28. Morris RE, Aird RE, Murdoch P, de S, Chen H, Cummings J, Hughes ND, Parsons S, Parkin A, Boyd G, Jodrell DI, Sadler PJ (2001) J Med Chem 44:3616-3621. doi:10.1021/jm010051m

29. Wang F, Chen H, Oswald IDH, Davidson JE, Sadler PJ (2003) Chem Eur J 9:5810-5820. doi:10.1002/chem.200304724

30. Peacock AFA, Habtemariam A, Fernández R, Walland V, Fabbiani FPA, Parsons S, Aird RE, Jodrell DI, Sadler PJ (2006) J Am Chem Soc 128:1739-1748. doi:10.1021/ja055886r

31. Schäfer S, Ott I, Gust R, Sheldrick WS (2007) Eur J Inorg Chem 3034-3046. doi:10.1002/ejic.200700206

32. Zagermann J, Kuchta MC, Merz K, Metzler-Nolte N (2009) J Organomet Chem 694:862-867. doi:10.1016/j.jorganchem. 2008.09.023

33. Pagano N, Wong EY, Breiding T, Liu H, Wilbuer H, Bregman H, Shen Q, Diamond SL, Meggers E (2009) J Org Chem 74:89979009. doi:10.1021/jo901641k 
34. Gopal YNV, Jayaraju D, Kondapi AK (1999) Biochemistry 38:4382-4388. doi:10.1021/bi981990s

35. Schultz C, Link A, Leost M, Zaharevitz DW, Gussio R, Sausville EA, Meijer L, Kunick C (1999) J Med Chem 42:2909-2919. doi: 10.1021/jm9900570

36. Bennett MA, Smith AK (1974) J Chem Soc Dalton Trans 233241. doi:10.1039/DT9740000233

37. Kiel W, Ball G, Graham AG (1990) J Organomet Chem 383:481496. doi:10.1016/0022-328X(90)85149-S

38. Bruker (2008) SAINT-Plus version 7.56a, Bruker AXS Inc, Madison

39. Sheldrick GM (1997) SHELXS-97, program for crystal structure solution, University of Göttingen

40. Sheldrick GM (1997) SHELXL-97, program for crystal structure refinement. University of Göttingen

41. Johnson GK (1976) Report ORNL-5138. Oak Ridge National Laboratory, Oak Ridge

42. Wilson AJC (ed) (1992) International tables for X-ray crystallography, vol C. Kluwer, Dordrecht

43. Schmeller T, Latz-Bruning B, Wink M (1997) Phytochemistry 44:257-266. doi:10.1023/A:1022315802264

44. Heffeter P, Jakupec MA, Körner W, Wild S, Graf v Keyserlingk N, Elbling L, Zorbas H, Korynevska A, Knasmüller S, Sutterlüty H, Micksche M, Keppler BK, Berger W (2006) Biochem Pharmacol 71:426-440. doi:10.1016/j.bcp.2005.11.009

45. Marko D, Schätzle S, Friedel A, Genzlinger A, Zankl H, Meijer L, Eisenbrand G (2001) Br J Cancer 84:283-289. doi:10.1054/ bjoc. 2000.1546
46. Chen H, Parkinson JA, Parsons S, Coxall RA, Gould RO, Sadler PJ (2002) J Am Chem Soc 124:3064-3082. doi:10.1021/ ja017482e

47. Dorcier A, Dyson PJ, Gossens C, Rothlisberger U, Scopelliti R, Tavernelli I (2005) Organometallics 24:2114-2123. doi:10.1021/ om049022a

48. Vock CA, Scolaro C, Phillips AD, Scopelliti R, Sava G, Dyson PJ (2006) J Med Chem 49:5552-5561. doi:10.1021/jm060495o

49. Renfrew AK, Phillips AD, Egger AE, Hartinger CG, Bosquain SS, Nazarov AA, Keppler BK, Gonsalvi L, Peruzzini M, Dyson PJ (2009) Organometallics 28:1165-1172. doi:10.1021/om800899e

50. Primik MF, Mühlgassner G, Jakupec MA, Dyson PJ, Arion VB, Keppler BK (2010) Inorg Chem 49:302-311. doi:10.1021/ ic902042a

51. Nguyen CH, Marchand C, Delage S, Sun JS, Garestier T, Helene C, Bisagni E (1998) J Am Chem Soc 120:2501-2507. doi: $10.1021 / \mathrm{ja} 971707 \mathrm{x}$

52. Sedlacek HH (2001) Crit Rev Oncol Hematol 38:139-170. doi: 10.1016/S1040-8428(00)00124-4

53. Karaman MW, Herrgard S, Treiber DK, Gallant P, Atteridge CE, Campbell BT, Chan KW, Ciceri P, Davis MI, Edeen PT, Faraoni R, Floyd M, Hunt JP, Lockhart DJ, Milanov ZV, Morrison MJ, Pallares G, Patel HK, Pritchard S, Wodicka LM, Zarrinkar PP (2008) Nat Biotechnol 26:127-132. doi:10.1038/nbt1358

54. McInnes C (2008) Drug Discov Today 13:875-881. doi:10.1016/ j.drudis.2008.06.012

55. Berthet C, Aleem E, Coppola V, Tessarollo L, Kaldis P (2003) Curr Biol 13:1775-1785. doi:10.1016/j.cub.2003.09.024 